\title{
REGULATORY ENTREPRENEURSHIP
}

\author{
Jordan M. Barry* \& Elizabeth Pollman**
}

Numerous corporations, ranging from Airbnb to Tesla, and from DraftKings to Uber, have built huge businesses that reside in legal gray areas. Instead of taking the law as a given, these companies have become agents of legal change; for each of them, changing the law is a major part of their business plan. To achieve their political goals, these companies employ conventional lobbying techniques, but also more innovative tactics. In particular, some attempt to enter markets quickly, then grow too big to ban before regulators can respond. If regulators do take aim at them, they respond by mobilizing their users for political support.

This Article offers the first focused study of what we term regulatory entrepreneurship - entering a line of business in which changing the law is a significant part of the business plan. We provide a framework for understanding this combination of business and political activity and a detailed account of the techniques that these companies employ. Further, the Article identifies and considers the conditions that are most likely to foster regulatory entrepreneurship, the prospects for regulatory entrepreneurship going forward, and its likely positive and negative implications for lawmaking.

\section{TABLE OF CONTENTS}

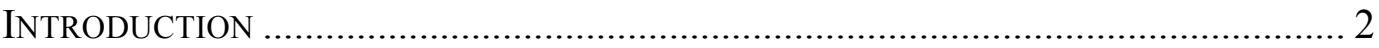

I. A THEORY OF REGULATORY ENTREPRENEURSHIP ........................................... 11

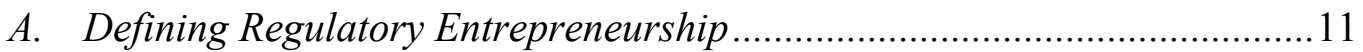

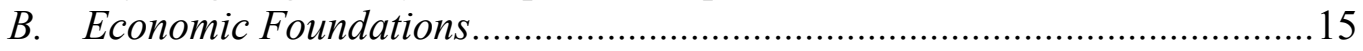

II. How REgUlatory ENTREPRENEURS InSTIGATE LEGAL CHANGE .................... 18

A. Breaking the Law or Taking Advantage of Legal Gray Areas....................... 18

B. Growing Too Big to Ban ........................................................................2

C. Mobilizing Users and Other Stakeholders for Political Power ...................23

D. More Traditional Political Techniques .....................................................25

III. Conditions that Foster Regulatory EntRePRENEURShiP ....................... 27

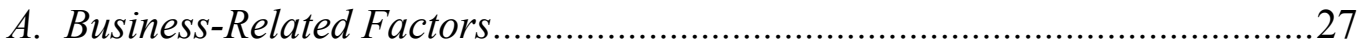

B. Law-Related Factors..........................................................................32

C. The Prevalence of Startups as Regulatory Entrepreneurs..............................38

IV. THE FUtURE OF REGULATORY ENTREPRENEURSHIP ...................................... 43

A. The Prospects for Regulatory Entrepreneurship Going Forward ...................43

B. How Regulatory Entrepreneurship Will Affect Legislation ............................47

1. The Political Process ......................................................................... 47

2. The Problem of Asymmetric Benefit Concentration ........................... 51

3. The Limits of Regulatory Entrepreneurship....................................... 56

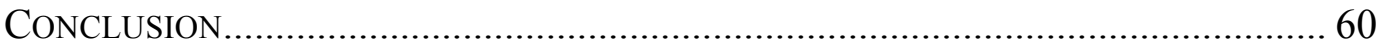




\section{INTRODUCTION}

A number of high-profile companies have devoted enormous amounts of time and money to entering lines of business that are legally fraught; the applicable laws are unclear, unfavorable, or both. These companies' fortuneswhether they will be bankrupt or worth billions 1 - often depend not only on the whims of the markets, but also on the resolution of legal issues concerning a core aspect of their business. These companies understand this, and each makes changing the law a material part of its business plan. We call this activity "regulatory entrepreneurship," and refer to the companies that engage in it as regulatory entrepreneurs.

As regulatory entrepreneurship has become more prominent in recent years, two major developments have come to the fore. First, regulatory entrepreneurs have experienced surprising political successes, securing significant policy victories over some of the country's most entrenched industry groups. ${ }^{2}$ Second, regulatory entrepreneurship has made huge inroads into startup culture. While startups largely used to eschew the political arena, many of the last decade's most successful startup companies are regulatory entrepreneurs.

Perhaps the country's most famous regulatory entrepreneur, and an example that we will return to throughout this Article, is Uber. Uber's business is

\footnotetext{
* Professor of Law, University of San Diego School of Law.

** Associate Professor of Law, Loyola Law School, Los Angeles. We thank Emily Keifer, Jay Bryan Barney, Brad Bernthal, Brian Broughman, Michael Burstein, Abe Cable, Mirit Eyal-Cohen, Jennifer Fan, Dov Fox, George Georgiev, Victor Fleischer, Michael Guttentag, Christine Hurt, Matthew Jennejohn, Orly Lobel, Peter Molk, Sean O'Connor, Frank Partnoy, Usha Rodrigues, Jeff Schwartz, Ted Sichelman, Gordon Smith, Mila Sohoni, Manuel Utset, and the participants at the Law and Entrepreneurship Association Retreat.

${ }^{1}$ See In re Napster Copyright Litig., Nos. C MDL 00-1369 MHP, 2006 WL 1348555 (May 17, 2006) ("[Napster] declared bankruptcy after abandoning its efforts to comply with the preliminary injunction entered by this court."); In re Aereo, Inc., No. 14-13200-2hl, 2014 WL 7721237 (Bankr. S.D.N.Y. 2014); Nathan McAlone, How Uber Became the Most Valuable Startup in the World, Bus. INSIDER (Sept. 14, 2015), http://www.inc.com/business-insider/how-uber-becamethe-most-valuable-startup-in-the-world.html; Sara Ashley O'Brien, Uber Is the Most Valuable Startup in the World, CNN MONEY (July 31, 2015, 3:47 PM), http://money.cnn.com/2015/07/31/technology/uber-50-billion-valuation/.

${ }^{2}$ For example, Uber has been making serious inroads against the taxi industry, and Tesla Motors has chalked up several victories against the car dealership lobby. See, e.g., Michael Gartland \& Danielle Furfaro, Voters Think Taxi Industry Had de Blasio in the Palm of Its Hand, N.Y. PosT (Aug. 10, 2015, 12:10 PM), http://nypost.com/2015/08/10/nyers-think-politicians-tried-to-limituber-due-to-yellow-cab-campaign-cash/; Sonari Glinton, Why Buying a Car Never Changes, NPR (Feb. 19, 2013, 6:42 PM), http://www.npr.org/sections/money/2013/02/19/172402376/whybuying-a-car-never-changes; Lee Hutchinson, FTC Doubles Down on Direct Auto Sales, Says "It's Not Just About Tesla", CARS TEChnICA (May 12, 2015, 8:49 AM), http://arstechnica.com/cars/2015/05/ftc-doubles-down-on-direct-auto-sales-says-its-not-just-abouttesla/.
} 
built around its popular smartphone app. ${ }^{3}$ The app connects people who want rides with drivers in the vicinity who are willing to provide them. Fares are determined based on an algorithm that takes into account factors related to supply and demand, and Uber takes a percentage of each fare. ${ }^{4}$ Uber is essentially running a taxi dispatch service for the smartphone age.

However, in most cities, the taxi cab industry is heavily regulated. ${ }^{5}$ Rules vary across jurisdictions, but they frequently require cabs to have a special government-issued license or medallion; these licenses are typically in very limited supply. ${ }^{6}$ Fares are often based on rigid prescribed formulas. ${ }^{7}$ Ten years ago, many observers would have said that the legality of Uber's business was questionable at best.

Uber was undeterred by these legal issues. It has aggressively taken on taxi regulations (and regulators) and worked to change the laws that govern taxi services. In a very concrete sense, Uber and many other recent startups are built around and based upon a plan to change the law-and, in some instances, to simply break the law in the meantime. ${ }^{8}$ For Uber-and many other companies like it - political activity has become a critical part of business strategy.

To be sure, corporate political activity is not a new phenomenon. Such activity has been the subject of federal regulation since $1907,{ }^{9}$ and has long been the subject of public controversy. ${ }^{10}$ But for much of U.S. history, large,

${ }^{3}$ Uber, https://www.uber.com (last visited Feb. 11, 2016) (explaining that a user can use their phone to "Tap the app, get a ride.").

${ }^{4}$ See Aswath Damodaran, A Disruptive Cab Ride to Riches: The Uber Payoff, ForBes (June 10, 2014, 2:37 PM), http:/www.forbes.com/sites/aswathdamodaran/2014/06/10/a-disruptive-cab-rideto-riches-the-uber-payoff/\#10a27ac664b8 (explaining the Uber business model).

5 See Paul Stephen Dempsey, Taxi Industry Regulation, Deregulation \& Reregulation: The Paradox of Market Failure, 24 TRANSPORTATION L.J. 73, 75-76 (1996) (“[N]early all large and medium-sized communities regulate their local taxicab companies.").

${ }^{6}$ See, e.g., id. at 78 (explaining that "[t]ypically, taxis are regulated at the local level, with city or county boards restricting the number of firms and number of taxis (with the issuance of medallions)" and that municipalities like New York City have strictly limited medallions, causing the price "to reach exorbitant levels"); Josh Barro, Under Pressure From Uber, Taxi Medallion Prices Are Plummeting, N.Y. Times (Nov. 27, 2014), http://www.nytimes.com/2014/11/28/upshot/under-pressure-from-uber-taxi-medallion-prices-areplummeting.html (explaining the medallion system and market).

${ }^{7}$ Barro, supra note 6.

${ }^{8}$ See supra Part II.A.

9 The Tillman Act prohibited "any national bank or corporation" from making "a money contribution in connection with any election to any political office." Ch. 420, 34 Stat. 864 (1907) (codified at 18 U.S.C. $§ 610$ (1948) (repealed 1976)). See generally Adam Winkler, Other People's Money: Corporations, Agency Costs, and Campaign Finance Law, 92 GEO. L.J. 871 (2004) (providing history).

${ }^{10}$ See Winkler, supra note 9, at 873-74 (arguing that early state and federal regulation of corporate political spending was motivated by concern about the corrupt nature of corporate managers misusing "other people's money" as well as "fears about excessive corporate power"); see also LeE Drutman, The Business of America Is Lobbying: How Corporations Became Politicized AND Politics BeCAME More CORPORATE 47-71 (2015). 
established companies dominated corporate political activity, often through trade associations. ${ }^{11}$ And, while corporate lobbying has grown increasingly proactive over time, ${ }^{12}$ it has been rare for a company to adopt a business model that explicitly focuses on seeking a change in the law. Companies have instead prioritized lobbying to protect their existing, legal businesses from cost-increasing regulations and to insulate themselves from competition. ${ }^{13}$ For example, U.S. auto manufacturers have long lobbied against increased fuel efficiency and emissions requirements that would make cars more expensive to produce-but these companies were not founded on a plan to roll back already-existing laws that made automobile production unprofitable or outright illegal. ${ }^{14}$

Moreover, the tactics that modern regulatory entrepreneurs are using differ from those that companies have historically relied upon to achieve their political goals. The conventional story of corporate political power relies on gaining quiet access to officials, then leveraging that access to exert influence behind the scenes. ${ }^{15}$ While regulatory entrepreneurs have used these tried-and-true methods, they have become better known, and arguably experienced greater success, from the opposite strategy: They make an issue as publicly salient as possible, rally the public to their cause, then use their popular support as a cudgel to beat the change they want from resistant officials.

For example, consider Uber's experience in New York City, the nation's largest market for taxi services and among the most tightly regulated. ${ }^{16}$ When faced with resistance by New York Mayor Bill de Blasio, Uber's user base was its biggest weapon. Uber offered free rides to passengers willing to attend a protest at City Hall on its behalf. ${ }^{17}$ It used its app to contact drivers and passengers and mobilize them to express their opposition to Mayor de Blasio's proposal, flooding

\footnotetext{
${ }^{11}$ See Lee Drutman, How Corporate Lobbyists Conquered American Democracy, ATLANTIC (Apr. 20, 2015), http://www.theatlantic.com/business/archive/2015/04/how-corporate-lobbyistsconquered-american-democracy/390822/.

${ }^{12}$ DrutMan, supra note 10, at 77, 238; David B. Yoffie \& Sigrid Bernstein, Creating Political Advantage: The Rise of the Corporate Political Entrepreneur, 28 CAL. Mgmt. Rev. 124, 124 (1985).

${ }^{13}$ See Drutman, supra note 11 (noting that when corporate political activity began to increase in the 1970s, leading corporations hired lobbyists and "[t]hey killed a major labor law reform, rolled back regulation, lowered their taxes, and helped to move public opinion in favor of less government intervention in the economy.").

${ }_{14}$ Alan Fram, U.S. Auto Lobby's Clout Flagging, ASSOC. Press (June 17, 2009, 12:01 AM), http://www.presstelegram.com/article/ZZ/20090617/NEWS/906179854.

${ }^{15}$ Drutman, supra note 10, at 30; see also PePPer D. CulPePPer, Quiet Politics AND Business POWER: CORPORATE CONTROL IN EUROPE AND JAPAN (2010).

16 See Alison Griswold, Uber Won New York, SLATE (Nov. 18, 2015, 5:01 AM), http://www.slate.com/articles/business/moneybox/2015/11/uber_won_new_york_city_it_only_too $\mathrm{k}$ five years.html.

${ }^{17}$ Giulia Olsson, Uber Protests Loudly Outside City Hall, N.Y. OBSERVER (June 30, 2015, 4:50 PM), http://observer.com/2015/06/uber-protests-loudly-outside-city-hall/. Uber also offered free t-shirts and sandwiches to passersby if they agreed to join the protest. $I d$.
} 
city hall with over 20,000 e-mails in five days. ${ }^{18}$ Uber also added a notable feature to its app: a "de Blasio" button that purported to show how users' experience would change if mayor de Blasio implemented his proposed policy. ${ }^{19}$ Users who pushed the button found that the app consistently predicted a twentyfive minute wait for a pick-up; ${ }^{20}$ they were then directed to a petition they could sign declaring their opposition to the mayor's proposed rule. ${ }^{21}$ Uber also benefited from an (apparently) impromptu social media campaign led by celebrity customers, including Kate Upton, Neil Patrick Harris, and Uber investor Ashton Kutcher. $^{22}$ The entire time, Uber was able to portray itself as the champion of its drivers, who would otherwise be out of work, and of its customers, who would be left out in the cold, their transportation needs unmet. ${ }^{23}$

To be clear, Uber also employed some more conventional strategies - but even there, it did so on a massive scale that, a decade ago, many would not have imagined possible for a startup company. It spent hundreds of thousands of dollars lobbying city officials, ${ }^{24}$ deploying a network of nationally and locally connected political operators to help it make its case in public and behind the scenes. ${ }^{25}$ It spent millions more on mailings, robocalls, and ads to sway New Yorkers to its side. ${ }^{26}$ It held events and issued press releases more reminiscent of a political campaign than a typical corporate public relations office. ${ }^{27}$

${ }^{18}$ Chris Smith, Battlin' Bill de Blasio's Uber Fight, N.Y. MAG. (July 22, 2015, 10:38 AM), http://nymag.com/daily/intelligencer/2015/07/battlin-bill-de-blasios-uber-fight.html.

${ }^{19}$ Flegenheimer \& Fitzsimmons, supra note 24; Tina Nguyen, Uber Takes Its War on New York City to Another Level, VANITY FAIR (July 16, 2015, 2:43 PM), http://www.vanityfair.com/news/2015/07/uber-takes-on-nyc-deblasio-over-proposed-driver-cap.

${ }^{20}$ Nguyen, supra note 19.

21 Edward T. Walker, The Uber-ization of Activism, N.Y. TIMES (Aug. 6, 2015), http://www.nytimes.com/2015/08/07/opinion/the-uber-ization-of-activism.html?_r=0.

${ }^{22}$ Adam Edelman et al., Kate Upton, Neil Patrick Harris, Ashton Kutcher Leàd Twitter War on Mayor de Blasio over Controversial Bill That Would Cap Uber's Growth, N.Y. DAILY NEws (July 23, 2015, 6:11 AM), http://www.nydailynews.com/news/politics/kate-upton-leads-celebritycharge-de-blasio-uber-article-1.2300747.

${ }^{23}$ Carolyn Said, Airbnb, Uber Cast Themselves As Saviors of the Middle Class, S.F. CHronicle (Nov. 10, 2015, 8:16 PM), http://www.sfchronicle.com/business/article/Airbnb-Uber-We-are-thesaviors-of-the-middle-6620729.php.

${ }^{24}$ Matt Flegenheimer \& Emma G. Fitzsimmons, City Hall and Uber Clash in Struggle Over New York Streets, N.Y. TimES (July 16, 2015), http://www.nytimes.com/2015/07/17/nyregion/city-halland-uber-clash-in-struggle-over-new-york-streets.html (stating that, since 2014, Uber had spent "at least $\$ 225,000$ on lobbying the mayor's office, the City Council and the Taxi and Limousine Commission").

25 These hires included David Plouffe, the architect of Barack Obama's successful 2008 presidential campaign; Stu Loeser, who served as press secretary to New York City mayor Michael Bloomberg; Alix Anfang, who previously worked for Eric Schneiderman, now New York's attorney general; Matthew Wing, former press secretary to New York Governor Andrew Cuomo; and Ashwini Chabra, deputy commissioner for policy and planning at the New York Taxi and Limousine Commission. Matt Flegenheimer, Taxi Commission Official Plans to Join Uber, N.Y. TIMES (May 20, 2014), http://www.nytimes.com/2014/05/20/nyregion/taxi-commissionofficial-plans-to-join-uber.html; Hartmann, supra note 26; Kurson, supra note 26.

${ }^{26}$ Margaret Hartmann, Was David Plouffe the Key to Uber's Deal with New York City?, N.Y. MAG. (July 23, 2015, 5:28 AM), http://nymag.com/daily/intelligencer/2015/07/david-plouffeuber-nyc.html (discussing Uber’s "stunning” $\$ 3.2$ million eight-day ad buy); Ken Kurson, 
Uber won its showdown in New York, ${ }^{28}$ at least for the time being. ${ }^{29}$ It has won many other fights in other jurisdictions across the country ${ }^{30}$ and around the world ${ }^{31}$ using a similar playbook. Though it has lost its share of battles, ${ }^{32}$ Uber's overall success in taking on taxi regulations has enabled it to grow into the world's most valuable private start-up corporation, ${ }^{33}$ with an estimated value of more than $\$ 60$ billion. $^{34}$

And while Uber is the country's highest-profile regulatory entrepreneur, there are numerous others as well. For example, consider Airbnb, the country's second-most-valuable private start-up. ${ }^{35}$ Its business is connecting property owners and renters with travelers in need of short-term lodging. ${ }^{36}$ This model has required Airbnb to contend with the many jurisdictions that limit short-term rentals to hotels and similar enterprises; Airbnb has changed these laws in many cities, including its hometown of San Francisco. ${ }^{37}$ The movement for marijuana

Revealed: Uber's TV Buy Is Gigantic, N.Y. OBSERVER (July 22, 2015, 9:20 AM), http://observer.com/2015/07/revealed-ubers-tv-buy-is-gigantic/ (calling it "eye-popping" and a "blitzkrieg").

${ }^{27}$ Kurson, supra note 26 (describing a press release with the title "Local Clergy and Faith Leaders Hold Media Availability with Uber Executive David Plouffe After Roundtable at Sylvia's Restaurant in Harlem").

${ }^{28}$ Matt Flegenheimer, Ending Fight, for Now, City Hall Drops Plan for Uber Cap, N.Y. TIMES, July 22, 2015, A20; Griswold, supra note 16.

29 Josh Dawsey, New York City Council Bypasses Mayor Bill de Blasio on Uber Policy, WALL ST. J. (Jan. 7, 2016, 8:49 PM), http://www.wsj.com/articles/new-york-city-council-bypasses-mayorbill-de-blasio-on-uber-policy-1452217772; Andrew J. Hawkins, Uber Is on a Collision Course with New York City's Mayor Again, THE VerGe (Dec. 4, 2015, 3:51 PM), http://www.theverge.com/2015/12/4/9851000/uber-nyc-bill-de-blasio-report-investigation-captax-cuomo.

${ }^{30}$ Uber, Find a City (last visited Feb. 6, 2016), https://www.uber.com/cities; Karen Weise, This Is How Uber Takes Over a City, BlOOMBERG Business (June 23, 2015), http://www.bloomberg.com/news/features/2015-06-23/this-is-how-uber-takes-over-a-city.

${ }^{31}$ Uber, Find a City (last visited Feb. 6, 2016), https://www.uber.com/cities; see also Ellen Huet, Uber's Global Expansion In Five Seconds, FORBES (Dec. 11, 2014, 6:00 AM), http://www.forbes.com/sites/ellenhuet/2014/12/11/ubers-global-expansion/\#690cc0177a7a.

32 Jenny Che, 9 Countries That Aren't Giving Uber An Inch, HuffPost Business (Aug. 12, 2015, 12:29 PM), http://www.huffingtonpost.com/entry/uber-countries-governments-taxidrivers_us_55bfa3a9e4b0d4f33a037a4b.

${ }^{33} \mathrm{McA} \overline{\mathrm{l}}$-one, supra note 1; O’Brien, supra note 1 .

${ }^{34}$ Leslie Picker \& Mike Isaac, Uber Said to Plan Another \$1 Billion in Fund-Raising, N.Y. TIMES (Oct. 23, 2015), http://www.nytimes.com/2015/10/24/business/dealbook/uber-said-to-plananother-1-billion-in-fund-raising.html.

35 Scott Austin et al., The Billion Dollar Startup Club, WALl ST. J. (Feb. 18, 2015), http://graphics.wsj.com/billion-dollar-club/; Davey Alba, AirBnB Confirms \$1.5 Billion Funding Round, Now Valued at \$25.5 Billion, WIRED (Dec. 7, 2015, 7:49 PM), http:/www.wired.com/2015/12/airbnb-confirms-1-5-billion-funding-round-now-valued-at-25-5billion/.

${ }^{36}$ Roberta A. Kaplan \& Michael L. Nadler, AirBnB: A Case Study in Occupancy Regulation and Taxation, 82 U. CHI. L. REV. Dialogue 103, 103-05 (2015).

37 See, e.g., id. at 107-12; Emily Badger, How Airbnb Just Changed the Housing Laws in San Francisco, WONKBLOG (Oct. 
legalization provides another example of regulatory entrepreneurship: ResponsibleOhio recently spent over \$20 million pushing a marijuana legalization initiative that would have given its backers the exclusive legal right to grow recreational marijuana in the state. ${ }^{38}$ Another regulatory entrepreneur, electric car manufacturer Tesla Motors, believes that it must sell its electric cars directly to consumers in order to fully succeed. ${ }^{39}$ This has required Tesla to battle state laws that require car manufacturers to sell through franchised dealerships, ${ }^{40}$ and it has already achieved significant victories in several states. ${ }^{41}$

While regulatory entrepreneurship has enormous implications for the law, it has received scant scholarly attention. This Article fills this gap in the literature, making four original contributions.

First, in Part I, the Article defines regulatory entrepreneurship and places it into context. We discuss how regulatory entrepreneurship differs from other forms of corporate political activity, and why regulatory entrepreneurship is a

https://www.washingtonpost.com/news/wonk/wp/2014/10/08/how-airbnb-just-changed-thehousing-laws-in-san-francisco/.

${ }^{38}$ Anne Saker, What You Need to Know About Marijuana Initiative, CInCINNATI (July 24, 2015, 12:52 PM), http:/www.cincinnati.com/story/news/2015/06/17/marijuana-ohio-ballotinitiativeresponsibleohio/28897081/. The group, ResponsibleOhio, ultimately failed. Jackie Borchardt, Pro-Marijuana Group ResponsibleOhio Dead, Founder Says, Won't Press Ballot Issue in 2016, CLeveland (Jan. 14, 2016, 6:10 PM), http://www.cleveland.com/open/index.ssf/2016/01/promarijuana_group_responsibl.html; David A. Graham, Why Did Ohio's Marijuana Legalization Push Fail?, ATLANTIC (Nov. 3, 2015), http:/www.theatlantic.com/politics/archive/2015/11/where-did-ohios-marijuana-legalizers-gowrong/414061/.

39 There is some reason to think that traditional car dealerships have poor incentives to promote electric cars. Electric cars require salespeople to invest time and energy to learn about them, and it currently takes a salesperson more time to complete the sale of an electric car than a gasolinepowered one. Service centers are a major part of modern dealerships, and electric cars such as Tesla's do not require dealer servicing in the way that gasoline-powered cars do. Many dealerships that sell electric and gas-powered cars discourage customers from buying the former and encourage them to buy the latter. See, e.g., Consumer Reports, Dealers Not Always Plugged in About Electric Cars, Consumer Reports' Study Reveals, CONSUMER REPORTS (Apr. 22, 2014, 8:00 AM), http://www.consumerreports.org/cro/news/2014/04/dealers-not-always-plugged-inabout-electric-cars-secret-shopper-study-reveals/index.htm; Nikki Gordon-Bloomfield, Consumer Reports: Dealerships Don't Understand, Like Electric Cars, TrAnsPORT EvOlved (Apr. 22, 2014); https://transportevolved.com/2014/04/22/consumer-reports-dealerships-dont-understandlike-electric-cars/; Cliff Weathers, How Tesla and New Car Technologies Could Make Auto Dealers Obsolete, SALON (Oct. 11, 2014, 5:00 http://www.salon.com/2014/10/11/how_tesla_and_new_car_technologies_could_make_auto_deal ers_obsolete_partner/.

${ }^{40}$ Daniel A. Crane, Tesla and the Car Dealers' Lobby, REgulation (Summer 2014), available at http://object.cato.org/sites/cato.org/files/serials/files/regulation/2014/7/regulation-v37n2-3.pdf.

41 See, e.g., Jonathan Stempel, Tesla Prevails in Top Massachusetts Court Over Direct Sales, REUTERS (Sept. 15, 2014, 5:16 PM), http://www.reuters.com/article/tesla-motors-massachusettslawsuit-idUSL1N0RG22Y20140915; Matthew DeBord, Maryland Carved Out an Innovative Special Exception for Tesla to Sell Cars Directly to Customers, Bus. InsIDER (Apr. 15, 2015, 5:31 $\mathrm{PM}$, http://www.businessinsider.com/maryland-carved-out-a-special-exception-for-tesla-to-sellcars-directly-to-customers-2015-4. 
politically and economically significant phenomenon. We then situate regulatory entrepreneurship in the economic theory on uncertainty and the entrepreneur as well as option theory, both of which provide important insights into what regulatory entrepreneurs do and the incentives that they face.

Second, in Part II, we examine the techniques that regulatory entrepreneurs employ in their efforts to change the law. We identify three creative techniques that modern regulatory entrepreneurs have adopted: They break the law and take advantage of legal gray areas, real or imagined, asking forgiveness instead of permission. They seek to grow "too big to ban" before regulators can act, sometimes referred to as "guerilla growth." Perhaps most dramatic, they mobilize their users and stakeholders as a political force. We illustrate each of these techniques with multiple real-world examples.

Third, the Article builds on Part II's analysis to determine the conditions that are most likely to foster regulatory entrepreneurship. In Part III, we identify and consider three variables that are of particular importance: the nature of the business, the nature of the laws creating uncertainty, and the company's stage and status. Businesses that are scalable, involve high degrees of connectivity, and that have mass appeal lend themselves best to guerrilla growth and political mobilization, and thus are best suited to a regulatory entrepreneurship model. State and local laws, which companies have greater ability to influence, provide more attractive opportunities for regulatory entrepreneurship than national laws. Moreover, entrepreneurs' ability to respond differently to conditions across a larger number of jurisdictions is valuable; even if events in one jurisdiction unfold unfavorably, other jurisdictions may produce more positive results. Thus, there is also greater diversification built into a state and local strategy. Finally, a company's status as a startup may affect its relative ability to engage in regulatory entrepreneurship. Compared to more established companies, startups have cultural and structural advantages.

Fourth, we explore the future of regulatory entrepreneurship. We begin Part IV by analyzing the prospects for regulatory entrepreneurship going forward. There are some reasons to think that the best opportunities for regulatory entrepreneurship are already being exploited. However, the market has become increasingly comfortable with regulatory entrepreneurship as a business strategy, and the infrastructure that has been assembled to date will facilitate new attempts at regulatory entrepreneurship on an ongoing basis. Perhaps most importantly, information technology continues to advance at an exponential pace. This will lower the cost of political engagement and make it easier for citizens to express their preferences, simultaneously creating new opportunities for companies to mobilize large groups of people on their behalf. Accordingly, we conclude that regulatory entrepreneurship is likely to increase in the years to come.

We also consider how regulatory entrepreneurship will affect the mix of laws and regulations that society ultimately enacts. In the political economy 
literature, there are a number of well-known and well-documented ways in which the political process can produce bad outcomes. For example, some laws and regulations provide concentrated benefits to particular interest groups, while imposing diffuse costs on the public. ${ }^{42}$ In these circumstances, the members of the relevant interest group have a strong incentive to advocate for the law in question. However, because the law's costs are spread over a much larger group, those who would be hurt by the law have little incentive to actively resist it. ${ }^{43}$ This can result in laws being enacted whose costs exceed their benefits. ${ }^{44}$

Regulatory entrepreneurship provides a way to combat some of these socially inefficient laws. In certain instances, it is possible to build a business that stands to benefit from repealing inefficient legislation and replacing it with a more economically efficient regime. This dynamic helps creates an actor that stands to receive concentrated benefits from reform, and thus one who will be willing to actively push for change.

For example, many cities regulate the supply of taxis and drivers. ${ }^{45}$ This benefits taxi companies by insulating them from competition. ${ }^{46}$ These same laws impose costs on consumers, who may have to wait longer for a worse, more

\footnotetext{
${ }^{42}$ Public choice theory elucidates how citizens can rationally decide not to participate in the political process because the costs outweigh the benefits to individual actors. See, e.g., Michael E. Levine \& Jennifer L. Forrence, Regulatory Capture, Public Interest and the Public Agenda: Toward a Synthesis, 6 J.L. ECON. \& ORG. 167, 189 (1990). Further, because of the rational apathy of the public, it follows that the law itself will tend to reflect the interests of small, cohesive interest groups rather than the public as a whole. See Jonathan R. Macey, Administrative Agency Obsolescence and Interest Group Formation: A Case Study of the SEC at Sixty, 15 CARDOZO L. REV. 909, 920-21 (1994); Zachary J. Gubler, Public Choice Theory and the Private Securities Market, 91 N.C. L. REV. 745, n.131 (2013).

${ }^{43}$ See Levine \& Forrence, supra note 42, at 189 (" $[T]$ he high costs to the public of becoming informed on issues which are specialized in their concentrated impact considerably influence the competition for public attention."); see also Richard A. Posner, Theories of Economic Regulation, 5 BELL J. ECON. \& MGMT. 335, 343 (1974) (discussing the economic theory of regulation and its idea that "economic regulation serves the private interests of politically effective groups").

${ }^{44}$ See George J. Stigler, The Theory of Economic Regulation, 2 BeLl J. ECON. \& MGMT. SCI. 3 (1971) (discussing when and why interest groups and industries are able to use regulations and the state for their own interests); Fred MCCheSney, Money for Nothing: Politicians, Rent EXTRACTION, AND POLITICAL EXTORTION (1997) (discussing how rent extraction and political extortion can result in law making to the detriment of the general public).

${ }^{45}$ Org. for Econ. Co-Operation \& Dev. (OECD), Policy Roundtables, Taxi Services: Competition and Regulation 2007, at 199-200 (2007) ("In the United States, taxi serves are regulated at the state or local level. . . . [M]ost major cities continue to regulate entry and fares in some manner, most also regulate the types of service that can be provided. .., vehicle and driver characteristics . ..., and service quality. ..”).

${ }^{46}$ See id. at 200-01 ("The stringency of entry regulation can manifest itself in the value of taxicab licenses. In a competitive, open entry market, the value of the right to serve the market would be zero. However, if the right to serve is restricted, the value of that right is capitalized in the price of the license. . . The fact that license values are substantial in several U.S. cities . . implies that entry restrictions have raised the rate of return in taxi service provision above that in other lines of endeavor and that prices are likely higher and the number of trips lower than they would be in the absence of regulation.").
} 
expensive cab ride. ${ }^{47}$ These laws also impose costs on those people who would like to drive passengers around for money but who are not permitted to do so. Many economists and scholars believe that the costs of these laws exceed their benefits. $^{48}$ However, the benefits are concentrated in the city's relatively small number of taxi companies, which have strong incentives to fight for these laws' enactment and to protect them once they are in place; in many instances, it will be their top political issue. ${ }^{49}$ Meanwhile, the costs are spread over hundreds of thousands or even millions of people, each of whom loses only a small amount and thus has little incentive to fight the law.

But Uber's existence changes these dynamics. Uber's business model essentially gives it a fraction of the benefits that consumers and would-be taxi drivers reap from repealing taxi regulation-each time Uber facilitates a transaction (one that taxi regulations would have prevented), Uber gets a portion of the transaction's value. ${ }^{50}$ This gives Uber a strong incentive to combat taxi regulations that create a barrier for entry; ${ }^{51}$ the more that Uber loosens those rules, the more transactions it can facilitate and the more that it stands to profit. Further, Uber's technology enables it to efficiently mobilize its network of users to help its political cause.

\footnotetext{
${ }^{47}$ See Dempsey, supra note 5, at 91-96 (describing how taxi regulation leads to the absence of a competitive market, imperfect information, transaction costs, and externalities); Brishen Rogers, The Social Costs of Uber, 82 U. CHI. L. Rev. Dialogue 85, 87 (2015) (“[D]eregulation efforts in the 1970s and 1980s failed: as in the 1920s, supply went up, but fares also went up and service declined.").

${ }^{48}$ See Katrina Miriam Wyman, Problematic Private Property: The Case of New York Taxicab Medallions, 30 YALE J. REG. 125, 125 (2013) (arguing that "New York taxicab licenses are an instance of inefficient private property rights sustained by political decision-making processes subject to pressures from powerful interest groups"); OECD, supra note 45, at 7 ("Restrictions on entry to the taxi industry constitute an unjustified restriction on competition. Regulatory capture frequently means that these restrictions lead to large transfers from consumers to producers, economic distortions and associated deadweight losses."); Adrian T. Moore \& Ted Balaker, Do Economists Reach a Conclusion on Taxi Deregulation?, 3 ECON. J. WATCH 109, 117 (2006) (concluding "the [economic] literature concluding that taxi deregulation is net beneficial is the richer literature"); Mark W. Frankena \& Paul A. Paulter, Fed. Trade Comm'n, An Econ. Analysis of Taxicab Reg. viii, Rank 37-66 (Bureau of Economics Staff Report, May 1984) ("The principal conclusion of this report is that no persuasive economic rationale is available for some of the most important regulations."). But see Dempsey, supra note 5, at 116-20 (supporting governmental planning and oversight of the taxi market); Chanoch Shreiber, The Economic Reasons for Price and Entry Regulation of Taxicabs, 9 J. TRANSPORT ECON. \& POL'Y 268 (1975).

${ }^{49}$ See Moore \& Balaker, supra note 48, at 111 ("[R]ent seeking plays a large role in taxi market regulation. There is large one source of pressure for most regulatory strictures-the incumbent taxi firms.").

${ }^{50}$ Uber's app facilitates this by solving the problem of market failures due to search costs for taxis. See, e.g., Robert Cairns \& Catherine Liston-Heyes, Competition and Regulation in the Taxi Industry, 59 J. PUB. ECON. 1-15 (1996) (creating models of taxi markets and finding that search costs lead to market failures).

${ }^{51}$ At least with respect to barriers that apply to Uber. See infra notes 321-329 and accompanying text.
} 
Yet we do not wish to paint regulatory entrepreneurship as a panacea, or even an unmitigated good. Regulatory entrepreneurs are profit-seeking entities, not saints, and they will generally use their political power to pursue the results that are best for themselves, not the results that are best for society. Accordingly, regulatory entrepreneurship is unlikely to fully solve any of the pathologies of the political system. Moreover, in some instances, regulatory entrepreneurship may have significant negative effects on society.

Overall, the likely effect of regulatory entrepreneurship is to make the government more responsive to business interests in general and certain types of companies in particular. Whether one considers this a positive or negative development will depend on one's view of those interests.

\section{A THEORY OF REgUlATORY ENTREPRENEURSHIP}

This Part sets out a theoretical framework of regulatory entrepreneurship. We first define and conceptualize the activity. We next examine the economic underpinnings of uncertainty and real option theory that help to explain the entrepreneurial action we observe in the world.

\section{A. Defining Regulatory Entrepreneurship}

All businesses face legal issues as part of their business operations. And companies naturally would like the laws that apply to them to be favorable.

But some companies enter a line of business that has a legal issue at its core - a significant uncertainty regarding how the law will apply to a main part of the business operations, a need for new regulations in order for products to be feasible or profitable, or a legal restriction that prevents the long-term operation of the business. Some companies enter this legally fraught business with the plan of eliminating these legal risks and issues by changing the law. For these entrepreneurs, political activity is generally a major component of their business models. Essentially, these companies are in the business of trying to change the law. We term such businesses "regulatory entrepreneurs," and this class of business activity "regulatory entrepreneurship.,"52 Regulatory entrepreneurship is

\footnotetext{
${ }^{52}$ We note that regulatory entrepreneurship is distinct from regulatory arbitrage. Regulatory arbitrage arises when parties change the form of their transaction, but not its substance, in order to effect more favorable regulatory treatment. In other words, it is about optimizing the legal cost of a transaction, given existing legal and regulatory structures. See Victor Fleischer, Regulatory Arbitrage, 89 TEX. L. REV. 227, 229-30 (2010) (defining regulatory arbitrage as "the manipulation of the structure of a deal to take advantage of a gap between the economic substance of a transaction and its regulatory treatment"); see also Jordan M. Barry, On Regulatory Arbitrage, 89 TEX. L. REV. SEE ALSO 69, 73 (2011) ("'R]egulatory arbitrage is a phenomenon that follows from having regulations that fail to take economic reality into account."); Frank Partnoy, Financial Derivatives and the Costs of Regulatory Arbitrage, 22 J. CORP. L. 211, 227 ("Regulatory arbitrage consists of those financial transactions designed specifically to reduce costs or capture profit opportunities created by differential regulation or laws."). Regulatory entrepreneurship, in contrast, is about taking on regulatory uncertainty.
} 
not a new phenomenon, but a spate of recent startup and technology companies have made it an increasingly salient one.

Of course, businesses have long engaged in political activity; corporations have been involved in U.S. politics since at least the 1800 s. $^{53}$ U.S. corporations and their trade associations spend billions of dollars each year on lobbying efforts. ${ }^{54}$ Nonetheless, regulatory entrepreneurship differs from long-established forms of corporate political activity in several significant ways.

Historically, corporate lobbying has been primarily a reactive endeavor. Companies have long lobbied to insulate themselves against competition. ${ }^{55}$ The growth of the regulatory state, and the increasing involvement of the government in the economic sphere, spawned a responsive increase in corporate politicking as companies fought to resist cost-increasing regulations-and, if possible, to capture the regulators and use them as another tool to insulate themselves against competition. $^{56}$

But by and large, corporate political activities have been, and continue to be, conducted by established businesses focused on protecting existing profit centers. It has been rare for a company to enter a line of business with the plan of changing the law. When companies have attempted to change the law, it has often been around the edges of existing businesses, shifting the boundaries to give a legal, profitable business more room to grow. For example, U.S. banks used to be limited to particular geographic areas; there were many legal hurdles to opening branches nationwide. ${ }^{57}$ Profitable banks kept pushing at these restrictions as they sought to expand their business, and the effect was a gradual weakening of the law's restrictions over time and a commensurate growth in banks' geographic scope. ${ }^{58}$ Legal change was valuable and helped fuel growth, but it was not a core part of the original business plan when the banks entered the business.

For regulatory entrepreneurs, this is not the case. They enter lines of business knowing that changing the legal environment is important for the business's growth, or even its legality, and with the intention of effecting that

\footnotetext{
${ }^{53}$ Mark A. Smith, American Business and Political Power: Public Opinion, Elections AND DEMOCRACY 6 (2000); Winkler, supra note 9, at 881.

${ }^{54}$ See, e.g., DRUTMAN, supra note 10, at 8 ("A total of 3,587 individual corporations reported a combined $\$ 1.84$ billion in lobbying expenditures, roughly 56 percent of all the disclosed money spent on lobbying in 2012. Add in another $\$ 553$ million in spending by trade associations and $\$ 175$ million in spending by business-wide associations, and that's $\$ 2.57$ billion in combined spending-78 percent of all the money spent on lobbying in 2012.").

${ }^{55}$ See DRUTMAN, supra note 10, at 3 (noting that corporate lobbying was historically "sparse and mostly defensive").

${ }^{56}$ See id. at 55 (describing "the political awakening of corporate lobbying" that begin in the 1970s after a period of new major regulatory laws).

${ }^{57}$ MeHrSA BARAdARAN, How THE OTHER HALF BANKS 27-34,144-47 (2015).

${ }^{58} I d$. at 51-63.
} 
change. Changing the law is not a side project, it is an integral part of the business plan.

Further, we believe that regulatory entrepreneurship has already proven to be a politically and economically significant phenomenon. Many regulatory entrepreneurs have scored significant political victories against some of the country's most entrenched interest groups. Regulatory entrepreneurs have produced legal changes that seemed quite unlikely a decade or two ago, including some victories that long eluded established, politically connected firms.

For example, many states prohibit vehicle manufacturers from selling directly to customers ("direct distribution"); instead, manufacturers must sell their cars through independent dealers. ${ }^{59}$ States enacted these laws to protect car dealers; in addition to imposing dealers as mandatory middlemen, they also make it difficult for manufacturers to terminate a dealership, even in the event of poor service or salesmanship. ${ }^{60}$ These laws have been in place for over fifty years, despite multiple attempts by the major car companies to pare them back. ${ }^{61}$

Electric car manufacturer Tesla Motors was founded in 2003 with the goal of proving that electric cars could be better than gasoline-powered cars. ${ }^{62}$ Because of the differences between gasoline-powered cars and Tesla's electric cars, especially with respect to the way that they are serviced, Tesla concluded that car dealers would not have good incentives to promote their cars. $^{63}$ Accordingly, from the beginning, Tesla's founders determined that direct distribution was critical to the success of its business model. ${ }^{64}$ Yet direct distribution was prohibited in many states. This means that Tesla started its business with the understanding that a change in the law was vital to the company's success. Given the political realities surrounding dealer franchise

59 Death of a Car Salesman, THE ECONOMIST (Aug. 22, 2015), http://www.economist.com/news/business/21661656-no-one-much-likes-car-dealers-changingsystem-will-be-hard-death-car-salesman; Elon Musk, To the People of New Jersey, Open Letter, Mar. 14, 2014, https://www.teslamotors.com/blog/people-new-jersey.

${ }^{60}$ Musk, supra note 59.

${ }^{61}$ See Death of a Car Salesman, supra note 59; Crane, supra note 40, at 12.

${ }^{62}$ Tesla Motors, https://www.teslamotors.com/about (last visited Jan. 16, 2016).

${ }^{63}$ Nikki Gordon-Bloomfield, Consumer Reports: Dealerships Don't Understand, Like Electric Cars, TRANSPORT EVOlved (Apr. 22, 2014), https://transportevolved.com/2014/04/22/consumerreports-dealerships-dont-understand-like-electric-cars/; Cliff Weathers, How Tesla and New Car Technologies Could Make Auto Dealers Obsolete, SALON (Oct. 11, 2014, 12:00 PM), http://www.salon.com/2014/10/11/how_tesla_and_new_car_technologies_could_make_auto_deal ers_obsolete_partner/.

${ }^{64}$ Tesla's registration statement in its initial public offering acknowledged: "Implementing our business model is subject to numerous significant challenges, including obtaining permits and approvals from local and state authorities, and we may not be successful in addressing these challenges. ... [W]e will need to persuade customers, suppliers and regulators of the validity and sustainability of our business model." Tesla Motors, Inc., Amendment No. 1 to Form S-1 Registration Statement, Jun. 2, 2011, at 22-23, available at http://ir.teslamotors.com/sec.cfm?view=all. See also Tesla Motors, https://www.teslamotors.com/about (last visited Jan. 16, 2016); Crane, supra note 40, at 1. 
laws, Tesla knew that it had create its own lobbying efforts to battle the car dealers' lobby for state legislative reforms. ${ }^{65}$ Car dealers have successfully blocked Tesla in several states, but the company has fought back and is slowly winning most of its fights. ${ }^{66}$ Thus, Tesla has made far greater inroads against the car dealership laws than more established car manufacturers have, despite these companies' far greater size, value, ${ }^{67}$ longevity, and perceived political power. ${ }^{68}$

Three more points merit emphasis here. First, we define regulatory entrepreneurship as a phenomenon that applies with respect to a line of business. For example, Google (now Alphabet) runs its well-known, clearly legal, and highly profitable search engine business. It is also pouring large amounts of resources into developing self-driving cars. Assuming that Google successfully develops the necessary technology to support this business, it still will not be viable or financially successful in the long term unless states change their laws in order to permit self-driving cars to use public roads. ${ }^{69}$ Google was well aware of this, and entered the self-driving car business intending to convince states to open their roads to its cars. By doing so, Google is engaging in regulatory entrepreneurship, even if Google's other lines of business and the continued viability of Google as a company overall do not depend on a change in the law.

Second, because regulatory entrepreneurship is primarily a profit-driven activity, it does not depend on legal formalities. Regulatory entrepreneurs do not necessarily care whether they effect a legal change on a de facto or de jure basis. For example, if the relevant regulatory body credibly commits to not enforcing

\footnotetext{
${ }^{65}$ Crane, supra note 40, at 1; Catherine Ho, PowerMoves, WaSH. Post (Nov. 18, 2015), https://www.washingtonpost.com/news/powerpost/wp/2015/11/18/powermoves-scrambling-toshape-refugee-policy-after-paris/ (noting that Tesla Motors hired lobbyist to lobby on automotive industry issues).

${ }^{66}$ Death of a Car Salesman, supra note 59. The FTC has come out in support of direct distribution auto sales. See Marina Lao et al., Direct-to-Consumer Auto Sales: It's Not Just About Tesla, FTC (May 11, 2015), https://www.ftc.gov/news-events/blogs/competitionmatters/2015/05/direct-consumer-auto-sales-its-not-just-about-tesla.

${ }^{67}$ As of February 2016, Ford Motor Company had a market capitalization that was more than twice the size of Tesla Motors (\$45 billion vs. $\$ 20$ billion). Yahoo!Finance, https://beta.finance.yahoo.com/quote/TSLA?1tr=1; https://beta.finance.yahoo.com/quote/F?1tr=1 (last visited Feb. 1, 2016).

${ }^{68}$ See Ford, Company Timeline, https://corporate.ford.com/company/history.html (last visited Feb. 1, 2016) (Ford Motor Company was incorporated in 1903); CATHERINE LUTZ \& ANNE LUTZ Fernandez, Carjacked: The Culture of the Automobile and Its EFFeCt on Our Lives (2010) (discussing the "formidable political power" of American automakers).

${ }^{69}$ See Claire Cain Miller, When Driverless Cars Break the Law, N.Y. TIMES (May 13, 2014), http://www.nytimes.com/2014/05/14/upshot/when-driverless-cars-break-the-law.html ("Only four states and the District of Columbia have passed laws specific to driverless cars, some just allowing manufacturers to test cars and none answering every legal question that might come up.”); Salvador Rodriguez, California, Google Ready For Autonomous Vehicle Showdown in 2016, I.B. TIMES (Feb. 15, 2:20 AM), http://www.ibtimes.com/california-google-ready-autonomous-vehicleshowdown-2016-2233290 ("California's lead in the race to autonomous, self-driving vehicles could come to a grinding halt should the state adopt draft measures announced this week that would all but make Google's driverless vehicles illegal.”).
} 
the law on the books, that is functionally just as good, from the entrepreneur's perspective, as amending the law.

Third, distinguishing regulatory entrepreneurs from other entrepreneurs is admittedly a matter of degree; at what point does changing the law become "important enough" to the company's business plan that the company becomes a regulatory entrepreneur? Nonetheless, it is useful to recognize that, for some businesses, changing the law is a material part of the business plan, and the implications that follow from this phenomenon.

\section{B. Economic Foundations}

Two economic theories are helpful in understanding regulatory entrepreneurship: the theory of uncertainty and real option theory.

Uncertainty refers to a situation or future event in which the outcome is unknown and for which a quantitative probability does not exist or cannot be measured. ${ }^{70}$ It is closely related to, but not the same thing as risk, which refers to a situation or future event in which the outcome is unknown but is a matter of a measurable probability, such as a coin flip that has a $50 \%$ chance of coming up heads or tails, or a Powerball ticket. ${ }^{71}$

A prominent line of economic theory holds that it is entrepreneurs' willingness to take on uncertainty that gives rise to profit. ${ }^{72}$ The classic version of this theory focused on two different types of uncertainty that an entrepreneur faces - the future demand she will attempt to satisfy and the future results of her operations. $^{73}$

In this Article, we focus on another, related dimension of uncertainty: the regulatory environment in which the business operates. There are myriad sources of regulatory uncertainty. It is uncertain whether lawmakers will amend or add to existing law-and, if so, when and in what way. ${ }^{74}$ It is uncertain how courts or agencies will apply existing law to a particular business activity. The extent and focus of enforcement may change over time. And so on. As the examples in this Article illustrate, taking on regulatory uncertainty can be a source of great profit, just like market uncertainty can be.

The economic theory pertaining to options also sheds light on some of the strategies and behavior that regulatory entrepreneurs employ. Option theory originates in finance. In basic terms, an option gives the holder the right, but not

\footnotetext{
${ }^{70}$ FrANK H. KNIGHT, RisK, UNCERTAINTY AND PROFIT 20 (1921).

${ }^{71}$ Id. at $19-20$.

${ }^{72}$ Id. at 232.

${ }^{73} \mathrm{Id}$. at 238 .

${ }^{74}$ We note that regulatory uncertainty does not necessarily mean that the law is unclear. If current law bans a particular business, but the law may be changed in the future, then regulatory uncertainty exists.
} 
the obligation, to buy or sell an asset within a specified period of time at a specified price. ${ }^{75}$ For example, if an investor has the right to buy one share of Apple stock for $\$ 100$ next Friday if she so chooses, she has an option to purchase Apple stock. This option will generate a profit for her if the market price of an Apple share exceeds $\$ 100$ next Friday. For instance, suppose the price of Apple stock is $\$ 150$. She can exercise her option and buy a share for $\$ 100$, then immediately sell it in the marketplace for the going price of $\$ 150$, pocketing a $\$ 50$ profit. Moreover, because she does not have to buy a share of Apple stock-i.e., she has the option to do so-she can always choose not to buy a share of Apple if doing so would not be in her interest. ${ }^{76}$ In that case, her option will expire unused and she will lose only what she paid to acquire the option. Thus, once acquired, an option can never have a negative value. ${ }^{77}$

Valuing options is complex, and the details are beyond the scope of this Article. However, two of the most important factors affecting an option's value are the amount of time that the option lasts for and the volatility of the underlying asset - that is, the amount that the price of Apple stock tends to move up or down in a given period of time. ${ }^{78}$ The longer the duration of the option, and the greater the volatility of the underlying asset, the more valuable the option becomes. The basic logic is that, over longer periods of time and with greater volatility, the range of values that the underlying asset might take on becomes more diffuse; the asset is more likely to significantly increase or decrease in value. If the asset gains value, the option holder will exercise the option and capture greater profits. If the asset loses value, the option holder's worst-case scenario is that exercising the option becomes unprofitable, in which case she will allow the option to expire unexercised; the option will never become worth less than zero. This combination of potentially unlimited upside and makes option holders favor risk and uncertainty.

Real option theory takes the insights described above and extends them to other actions besides buying and selling financial assets. ${ }^{79}$ A "real option" thus refers to the right, but not the obligation, to take an action-such as building a

\footnotetext{
${ }^{75}$ See, e.g., Avinash K. Dixit \& Robert S. Pindyck, The Options Approach to Capital Investment, HARV. BUS. REV., May-June 1995, at 105.

${ }^{76}$ For example, if Apple shares were selling in the marketplace for $\$ 75$ a share next Friday, she would be foolish to exercise the option and pay $\$ 100$ when she could buy an equivalent share through ordinary channels for $\$ 25$ less.

77 See Richard A. Brealey, Stewart C. Myers \& Franklin Allen, Principles of CORPORATE FINANCE 515 (10th ed. 2011).

${ }^{78}$ These matters are the purview of option pricing theory, which concerns how markets value financial options such as puts and calls on corporate stock. See Fischer Black \& Myron Scholes, The Pricing of Options and Corporate Liabilities, 81 J. POL. ECON. 637 (1973); Fischer Black et al., The Capital Asset Pricing Model: Some Empirical Tests, in STUDIES IN THE THEORY OF CAPITAL MARKETS 79 (Michael Jensen ed., 1972).

79 See, e.g., Ronald J. Gilson \& Bernard S. Black, The Law and Finance of Corporate ACQUISITIONS 64 (2d ed. 1995).
} 
new factory, hiring or firing workers, filing for a patent, etcetera. ${ }^{80}$ The value of the real option lies in the flexibility it provides to adapt to market developments; the option holder has the full term of the option in which to make a decision about taking action. ${ }^{81}$ Accordingly, "[t]he more uncertain the outlook, the more valuable this flexibility becomes" as it allows for decisionmaking as new information comes to light. ${ }^{82}$ Real option pricing models reflect that the value of a potential project is not simply a comparison of the cost versus the present value of future cash flows across potential outcomes, because companies have the ability to step up operations in "good" scenarios and scale them down in "bad" scenarios. In short, there is value in having a right to alter the project (expand, abandon, delay, etc.) at various stages in development.

Regulatory entrepreneurs are real option holders - they have the ability to adjust their conduct over time in response to changed conditions. ${ }^{83}$ Consider a company that is deciding whether to enter a line of business that falls within a legal gray area. There are numerous regulatory uncertainties that make this type of decision difficult: Will regulators enforce existing laws against the company? In which jurisdictions will regulatory enforcement occur? Will regulators enact new laws that aid or ban the business? If the company had to make all of its decisions ex ante, it might decide not to begin at all. But, in practice, the process of moving toward regulatory certainty can often be broken into steps, and the company can decide to abandon development at various points along the way. ${ }^{84}$ This enables the company to limit the likelihood that it will invest significant resources in a product that it will never be able to profitably sell in the market. Knowing about these possibilities in advance, the company will be more likely to enter the line of business in the first place. Because the value of a real option increases with the uncertainty that the option holder faces, increased regulatory uncertainty can make a regulatory entrepreneurship strategy more attractive. Moreover, because an option's value increases with its duration, regulatory entrepreneurs may wish to draw out the process of resolving any regulatory uncertainty.

\footnotetext{
80 Thomas A. Smith, Real Options and Takeovers, 52 EMORY L.J. 1815, 1817 (2003). Legal scholars have applied real option theory to a variety of areas of law. See, e.g., id.; Christopher A. Cotropia, Describing Patents As Real Options, 34 J. CoRP. L. 1127, 1129 (2009); Joseph A. Grundfest \& Peter H. Huang, The Unexpected Value of Litigation: A Real Options Perspective, 58 STAN. L. REV. 1267 (2006);

${ }^{81}$ Lenos Trigeorgis, ReAl Options: Managerial Flexibility and Strategy in Resource AlloCATION ix-x (1996); see also Cotropia, supra note 80, at 1129.

82 Richard A. BREAley ET AL., PRINCIPLES OF CORPORATE FinANCE 16-18 (8th ed. 2006).

${ }^{83}$ We note also that shareholders of corporations and members of LLCs are option holders because of limited liability. They can always choose to abandon their stock or membership interest and walk away at any time, effectively choosing not to buy the company from its creditors. Shaun Martin \& Frank Partnoy, Encumbered Shares, 2005 U. ILL. L. REV. 775.

${ }^{84}$ Similarly, if demand is higher than expected, the company can ramp up production in response.
} 


\section{How Regulatory Entrepreneurs InStigate Legal Change}

We now explore the mechanisms that regulatory entrepreneurs employ to change the law. These include conventional political strategies, such as corporate lobbying. However - perhaps unsurprisingly, as many regulatory entrepreneurs are innovative startup companies - they have also adopted creative new tactics to achieve their political goals. In this Part, we explore how the most effective regulatory entrepreneurs weave together new and time-tested tactics to create a larger strategy.

\section{A. Breaking the Law or Taking Advantage of Legal Gray Areas}

Many regulatory entrepreneurs follow the maxim that it is better to beg forgiveness than to ask for permission. In this context, that translates to "it is better to enter markets and start providing services to the public - legally or otherwise - than to seek approval from regulators." Companies often justify this behavior by construing some gray area in the law as permitting the action in question. It helps that regulatory entrepreneurs often have new business models, frequently built on new technology: Because law often lags technology, companies may plausibly be able to claim that existing laws do not clearly address their precise circumstances.

A motivated entrepreneur can often manufacture a legal gray area, blurring the line between outright lawbreaking and aggressive interpretation: Even if existing regulations or statutes use broad language that would, when read literally, prohibit the company's business model, companies can take the view that officials were not considering the company's business model when the laws were written - how could they, when the model did not yet exist? Thus, they can assert that the laws were not meant to cover their new circumstances, and that courts will construe them accordingly.

It is difficult to know from an outside perspective whether particular companies are deliberately violating laws, and in many instances there is at least room for argument about the matter. For our purposes, it suffices (and we believe it is fair) to say that when regulatory entrepreneurs move into a market, they often take an aggressively favorable reading of the relevant law, and that the correctness of their interpretation - that is, whether or not they are actually complying with the law initially - is not a first-order concern. ${ }^{85}$

\footnotetext{
${ }^{85}$ The many public reports of startup companies ignoring notifications of their illegal activity suggests that this is part of a larger strategy combining business and politics. See, e.g., Serena Saitto, Inside Big Taxi's Dirty War with Uber, BloOMBERG BusINESS (Mar. 11, 2015, 5:00 AM), http://www.bloomberg.com/news/articles/2015-03-11/inside-big-taxi-s-dirty-war-with-uber

("Uber's strategy has been to launch services regardless of the rules and then leverage its popularity to force regulators to adapt. So far, that approach has succeeded in about 30 markets in North America, ... . where new laws on licensing and safety have been created for so-called transportation network companies like Uber are in the process of being approved.").
} 
This state of affairs - operating and growing their business, while taking the questionable position that they are acting within the bounds of the lawgenerally benefits regulatory entrepreneurs. They typically opt to continue it as long as possible, which means at least until regulators and enforcement agencies come knocking. Thus, in sum, many regulatory entrepreneurs' approach includes strategically operating in a zone of questionable legality or breaking the law until they can (hopefully) change it. This behavior reflects the principle of optionality discussed above - the company effectively extends the duration of its real options. This increases the company's value because all it stands to lose is the investment made to date and the upside could be huge.

For example, early in Uber's operations, the company was reported to have received and ignored a cease-and-desist demand from transit regulators in its first city, San Francisco. ${ }^{86}$ The company has followed the same playbook in other cities when problems have arisen, even internationally. Uber and its executives have been embroiled in legal battles in Paris, for instance, after refusing to shut down its "UberPop" service following the passage of a transportation law that made it illegal. ${ }^{87}$ Despite police crackdowns, Uber has repeatedly paid drivers' fines and continued to advertise on radio stations. ${ }^{88}$

Uber's main competitor, Lyft, has taken a similar approach. In a court filing, the New York state attorney general's office claimed:

As it has done in every other city in which it operates, defendant has simply waltzed into New York and set up shop while defying every law passed whose very purpose is to protect the People of the State of New York. Despite being warned and told to cease and desist by three separate regulatory and enforcement agencies, defendant has thumbed its nose at the law and continued with its plan to launch in what could become its largest market. ${ }^{89}$

As another example, technology investors have placed bets in the mobile payments and virtual currencies space, an area of innovation that raises significant legal questions. Marc Andreessen, the principal of a leading venture capital (VC) firm, recounted the advice that one of his lawyers had given on the topic of the

\footnotetext{
${ }^{86}$ Marcus Wohlsen, Uber's Brilliant Strategy to Make Itself Too Big to Ban, WIRED (July 8, 2014, 6:30 AM), http://www.wired.com/2014/07/ubers-brilliant-strategy-to-make-itself-too-big-to-ban/.

${ }^{87}$ See Aurelien Breeden \& Mark Scott, Uber Executives' Trial in Paris Is Postponed, N.Y. TIMES (Sept. 30, 2015), http://www.nytimes.com/2015/10/01/business/uber-france-trial-executives.html; Liz Alderman, Uber's French Resistance, N.Y. TIMES (June 3, 2015), http://www.nytimes.com/2015/06/07/magazine/ubers-french-resistance.html.

${ }^{88}$ Alderman, supra note 87 (quoting the general manager of Uber France: "We tell [drivers], if you get fined, come to us and we'll support you. We want them to feel as confident as we feel about what we're doing and our interpretation of the law.").

${ }^{89}$ Memorandum of Law in Support of Motion for Temporary Restraining Order and Preliminary Injunction, People of the State of N.Y. vs. Lyft, Inc., July 11, 2014, available at http://cdn2.voxcdn.com/assets/4744462/MOL.PDF.
} 
virtual currency bitcoin" " "Good news guys. Here you have a financial instrument that can be simultaneously regulated as a currency, a commodity, and a security. . . Regulators will fight over who, exactly, gets to regulate it, and $V C$ 's job is to sneak through the fight." 91

Yishan Wong, a Silicon Valley angel investor who was an early PayPal employee and formerly the CEO of Reddit, explained a similar view:

[I]f you are a startup who feels that the violation of a law (or an excursion into a grey and questionable/undefined area of the law) will allow you to create a business that provides enormous value to people, the tactically wise thing to do is to move forward and try to build the business. Moreover, if your business is not doing something morally egregious (e.g. killing people) but simply violating the law in a somewhat more minor way, the officers of the company bear little more risk than the company being sued out of existence, i.e. they bear little personal risk besides opportunity cost. $^{92}$

He further explained that "[t]he law and its subsequent enforcement are often defined by the will of the people." 93 Moreover, "if there is a business that a lot of people like but is in gross violation of the law, it is typically allowed to stand, either via a subsequent modification of the law, clarifications in the grey area which end up being favorable to the business, or lax enforcement." "94

\section{B. Growing Too Big to Ban}

Timing plays an important role in a strategy to break the law or operate in a gray area of the law: Early movers may establish a market position that will in

90 Kevin V. Tu \& Michael W. Meredit, Rethinking Virtual Currency Regulation in the Bitcoin Age, 90 WASH. L. REv. 271, 277 (2015) ("As a type of virtual currency, Bitcoin is a medium of exchange that (1) is electronically created and stored, and (2) lacks the backing of a government authority, central bank, or a commodity like gold. Like traditional currency, virtual currencies such as Bitcoin can be used to purchase goods and services from any person that is willing to accept it as a form of payment.").

${ }^{91}$ Carmel DeAmicis, Andreessen: Bitcoin is Like the Early Internet, PANDODAILY (Oct. 3, 2013), http://pandodaily.com/2013/10/03/andreessen-bitcoin-is-like-the-early-internet/ (emphasis added); see also Written Statement of Aaron J. Greenspan, Chief Executive Officer, Think Computer Corporation, Before the U.S. Senate Comm. on Banking, Housing, and Urban Affairs, Nov. 19, 2013, at 13, available at http://www.aarongreenspan.com/writing/20131118.hsgacstatement.pdf (quoting Marc Andreessen); Noam Scheiber, Uber and Airbnb Are Waging a Libertarian War on Regulators, New RePUBLIC (May 20, 2014), https://newrepublic.com/article/117837/airbnb-uberwage-war-regulators-army-customers. (discussing that many financial and payment technology companies have made a "rational calculation" to take a "shoot-first/ask-questions-later strategy").

92 Yishan Wong's answer to "Airbnb: Why has Airbnb not been sued or regulated out of existence?", https://www.quora.com/Airbnb/Why-has-Airbnb-not-been-sued-or-regulated-out-ofexistence.

${ }^{93} I d$.

${ }^{94} I d$. 
turn affect their leverage vis-à-vis the government and the ultimate success of their business model. To again quote Mr. Yishan Wong:

In the case of Airbnb, the likely time it will take for entrenched business interests to react to Airbnb, for a debate about enforcement and clarification of the law, and then for regulations to be proposed, debated, amended, passed, and then enforcement measures taken is likely to be more time than it will take for Airbnb - moving at internet speed - to establish itself as a globally viable business. By the time that happens, the market (i.e. the democratic majority) will probably have shifted to favor its interests, so long as they continue to operate the business in a way that benefits travelers and would-be amateur hoteliers. ${ }^{95}$

Other commentators have aptly described this approach as "guerrilla growth" or aiming to grow "too big to ban." business, but it is particularly so for a regulatory entrepreneur. Some regulatory entrepreneurs pursue rapid growth not just to improve their valuation or prospects for profits, but also to gain political advantage against regulators that might seek to ban or regulate the business activity. Business growth can translate to consumer popularity that becomes difficult for regulators to ignore.

Uber again illustrates this point clearly. Uber makes its money by taking a percentage of the driver's fare. ${ }^{97}$ On numerous occasions, Uber has dramatically cut its prices in order to increase its user base, valuing growth over profitability. ${ }^{98}$ At times, Uber has cut its prices to such a great extent that it effectively paid customers to use its service. $^{99}$

Loss leaders are well-known in business, ${ }^{100}$ but it is rare for a company's main product to be one. ${ }^{101}$ Ordinarily, this would evoke the old business joke about losing money on every sale, but making it up in volume. But for Uber, this was considered a savvy strategy because "[i]f [Uber] gets big enough quickly

\footnotetext{
${ }^{95} I d$.

${ }^{96}$ Wohlsen, supra note 86; Callum Borchers, DraftKings and FanDuel Vie to Become 'Too Big To Ban', WASH. POST (Nov. 12, 2015), https:/www.washingtonpost.com/news/thefix/wp/2015/11/12/why-are-draftkings-and-fanduel-all-over-your-tv-because-they-want-to-be-toobig-to-ban/.

97 Ellen Huet, Uber Tests Taking Even More From Its Drivers With 30\% Commission, ForBES (May 18, 2015, 6:32 PM), http://www.forbes.com/sites/ellenhuet/2015/05/18/uber-new-uberxtiered-commission-30-percent/.

${ }^{98}$ Wohlsen, supra note 86.

${ }^{99}$ Id.; see also Uber, Business (last visited Jan. 29, 2016), https://www.uber.com/business (noting that "the uberx option is up to $40 \%$ cheaper than a taxi").

${ }^{100}$ A loss leader is a product intentionally sold at a loss in order to stimulate sales of other, profitable items.

${ }^{101}$ Wohlsen, supra note 86 (describing how Uber usually takes a $20 \%$ commission, but that it cut fares in San Francisco and Los Angeles by $25 \%$ and made up the difference to drivers, essentially paying part of the fare for its passengers in those areas).
} 
enough, the political price could become too high for any elected official who tries to pull Uber to the curb."102 Another commentator remarked: "[I]t has already outgrown the stage at which its growth could have been squelched by aggressive regulatory action, à la the Internet-TV startup Aereo. At this point, any regulatory crackdowns will only serve to define the contours of Uber's dominance." $" 103$ Politicians have taken notice of the political dimension to this growth. A California State Assembly member who sponsored a measure to regulate Uber remarked: "They wanted to get themselves established very quickly as the bully you didn't want to mess with."104

Another recent example of companies taking the too-big-to-ban strategy includes fantasy sports gaming sites FanDuel and DraftKings. These companies charge a fee for users to play online auction-based fantasy games; the companies keep a percentage of the fees and pay out the rest as prizes. ${ }^{105}$ Both FanDuel and DraftKings have prioritized growth over profits; they return large percentages of their revenues back to users in the form of prize money and spend millions on advertising during sports broadcasts. ${ }^{106}$ These firms are credited with creating a new industry in fantasy sports that barely existed just a couple of years ago, but that is now projected to produce $\$ 31$ billion in player entry fees and $\$ 2.6$ billion in net revenue by $2020 .^{107}$

After a recent determination by New York's attorney general that the gaming sites are breaking the law, FanDuel and DraftKings both released statements invoking their size and popularity and questioning the state's attempt to shut them down. FanDuel's statement read, in part: "This is a politician telling hundreds of thousands of New Yorkers they are not allowed to play a game they love and share with friends, family, coworkers and players across the country."108 DraftKings similarly stated: "We strongly disagree with the reasoning in [the] opinion and will examine and vigorously pursue all legal options available to

\footnotetext{
${ }^{102} I d$. ("By drastically lowering its prices, Uber is doing more than increasing its customer base. It's cultivating constituents - the people who will complain when someone in power tries to take away their Uber.").

103 Will Oremus, The End of the Taxi Era, SLATE (Jan. 8, 2016, 5:58 PM), http://www.slate.com/articles/technology/technology/2016/01/yellow_cab_in_san_francisco_is_ju st the beginning_uber_s_war_on_cabs_is.html.

${ }^{10 \overline{4}}$ Rosalind S. Helderman, Uber Pressures Regulators By Mobilizing Riders and Hiring Vast Lobbying Network, WASH. POST (Dec. 13, 2014), https://www.washingtonpost.com/politics/uberpressures-regulators-by-mobilizing-riders-and-hiring-vast-lobbyingnetwork/2014/12/13/3f4395c6-7f2a-11e4-9f38-95a187e4c1f7_story.html.

${ }^{105}$ Ben Fischer, FanDuel vs. DraftKings: Are We Seeing the Future of Sports Wagering?, N.Y.

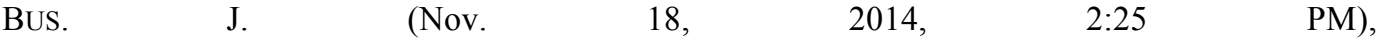
http://www.bizjournals.com/newyork/blog/techflash/2014/11/fanduel-vs-draftkings-are-weseeing-the-future-of.html.

${ }^{106}$ Noah Kulwin \& Kurt Wagner, It's No Good! DraftKings, FanDuel Deemed Illegal in New York, RE/CODE (Nov. 10, 2015, 4:29 PM), http://recode.net/2015/11/10/its-no-good-draftkingsfanduel-deemed-illegal-in-new-york/.

${ }^{107} I d$.

${ }^{108} I d$.
} 
ensure our over half a million customers in New York State can continue to play the fantasy sports games they love."

\section{Mobilizing Users and Other Stakeholders for Political Power}

An especially interesting strategy in the regulatory entrepreneurship toolbox has been to use customers and other stakeholders to fight corporate political battles. Not all companies are well-loved enough by the public for this to be viable, but for those with the support of their users and stakeholders it has proven a particularly effective tactic. Popular support is a valuable commodity in the political arena, and irate would-be customers are a more sympathetic face to put on an issue than the company's bottom line.

For example, Virginia's Department of Motor Vehicles sent Uber a ceaseand-desist order notifying the company that its service was illegal and that it needed to immediately cease all operations in the state. ${ }^{110}$ Uber responded by sending a notice to all of its Virginia users, along with the contact information for the ordinarily low-profile state official involved in the decision. Within a few days, hundreds of angry Uber customers had emailed the official, inundating his inbox and requiring him to work all weekend to respond. ${ }^{111}$ Uber also hired a team of lobbyists in Virginia and, within 48 hours, the state's transportation secretary instructed the DMV not to interfere with Uber drivers. ${ }^{112}$ Uber lobbyists then submitted a proposed temporary operating permit, which state officials granted several weeks later, permitting the company (as well as Uber competitor Lyft), to continue their normal operations. ${ }^{113}$

Uber has repeatedly used this tactic of sending alerts to riders on their phones, asking them to sign petitions or contact public officials at key political moments for the company. ${ }^{114}$ The company reports that nearly half a million riders have signed petitions. ${ }^{115}$ Its users often respond quickly and in vast numbers - reportedly at a rate of seven electronic signatures per second in some instances. ${ }^{116}$ When the Illinois General Assembly passed a restrictive measure that would negatively impact Uber's business, Uber used its smartphone app to mobilize its army of users. It inserted a splash screen and emailed Illinois riders requesting that they sign a digital petition asking the state governor to veto the bill. Twenty-five thousand supporters signed the petition in its first hour. ${ }^{117}$

\footnotetext{
${ }^{109} \mathrm{Id}$.

${ }^{110}$ Helderman, supra note 104.

${ }^{111} \mathrm{Id}$.

${ }^{112} \mathrm{Id}$.

${ }^{113} \mathrm{Id}$.

${ }^{114} I d$.

${ }^{115} \mathrm{Id}$.

${ }^{116} \mathrm{Id}$.

${ }^{117} I d$. The governor eventually vetoed the bill and Uber used traditional lobbying techniques to successfully fight a legislative effort to override the veto. $I d$.
} 
In Portland, when faced with a city ordinance that was an obstacle to its black car ride service, Uber announced on its blog that it would run a one-day promotion delivering free ice cream around the city. ${ }^{118}$ The ice cream "delivery" event provided the company with a database of people who were likely to be sympathetic to its goals, and who it could then turn into advocates for its ride sharing service. ${ }^{119}$ Almost 1,700 people signed a petition to allow the company to operate in the city. ${ }^{120}$ When Uber later launched its UberX service in the city before the service had been officially sanctioned, the company carefully used hyper-local marketing to appeal to Portland residents, such as creating an ad with a well-known quirky unicyclist bagpiper as the first rider. ${ }^{121}$ The company then threw itself a party at which attendees could take photos with protest signs or send a postcard to the mayor. ${ }^{122}$ In the first four hours, more than 7,000 people signed a petition in support of Uber operating its service in Portland. ${ }^{123}$ Uber's key political strategist, David Plouffe, has drawn a parallel between customers and campaign volunteers. ${ }^{124}$

Airbnb has also leveraged its users for political advantage. The company recently announced plans to create and support "clubs" in 100 U.S. cities to help residents campaign against local rules restricting short-term rentals. ${ }^{125}$ Airbnb expects hosts and guests who use their service to run the clubs, which have been likened to local unions. ${ }^{126}$ The company's global policy chief stated, "We'll spend what it takes to succeed." 127

This strategy comes on the heels of Airbnb's $\$ 8.4$ million ground campaign in San Francisco, in which the company mobilized hosts and guests to defeat a local proposition that would have limited short-term rentals. ${ }^{128}$ Over 2,000 volunteers knocked on over 285,000 doors in the city in order to gain political support for Airbnb's cause. ${ }^{129}$ Until recently, such mobilized grassroots support for a multibillion-dollar company has been unheard of, or at least highly unusual. $^{130}$

\footnotetext{
${ }^{118}$ Weise, supra note 30.

${ }^{119} \mathrm{Id}$.

${ }^{120} I d$.

121 Uber, Portland's Very Own Unipiper is Rider Zero!, (Dec. 5, 2014), https://newsroom.uber.com/pdx/portlands-very-own-unipiper-is-rider-zero/.

${ }^{122}$ Weise, supra note 30.

${ }^{123} I d$.

${ }^{124} \mathrm{Id}$.

${ }^{125}$ Heather Somerville, Airbnb to Create 100 Clubs to Advocate for Home-Sharing, REUTERS (Nov. 4, 2015, 7:06 PM), http://www.reuters.com/article/us-airbnb-sanfranciscoidUSKCN0ST2RL20151105.

${ }^{126}$ Id.; Conor Dougherty \& Mike Isaac, Airbnb and Uber Mobilize Vast User Base to Sway Policy, N.Y. TIMES (Nov. 4, 2015), http://www.nytimes.com/2015/11/05/technology/airbnb-and-ubermobilize-vast-user-base-to-sway-policy.html.

${ }^{127}$ Somerville, supra note 125.

${ }^{128} I d$.

${ }^{129} \mathrm{Id}$.

${ }^{130}$ Airbnb was recently valued at $\$ 24$ billion-higher than the valuation of the mega-hotel chain Marriott International. See Dougherty \& Isaac, supra note 126.
} 
And, indeed, this kind of regulatory entrepreneurship raises the question of whether such political support can be called grassroots when it has been catalyzed from the top-down as part of a corporate strategy. It was Airbnb's own global policy chief, previously a D.C. political operative, who framed the business as a "movement" at a San Francisco news conference: "There is going to be more people doing home-sharing tomorrow than there are today, there is going to be more the day after that. This is now a movement."131

Similarly, when fantasy gaming sites FanDuel and DraftKings found themselves in the political spotlight, they catalyzed fans and informed them of their efforts and what the fans could do to help. ${ }^{132}$ Efforts included writing a charter for a new fantasy sports trade association, asking a former federal judge and attorney general to review the company's practices, forming an advisory board led by a former United States Attorney General for the Southern District of New York, and proactively trying to work with state legislators to adopt consumer protection requirements such as age verification that would allow the companies to continue to operate and grow. ${ }^{133}$ FanDuel's CEO further noted that in just two weeks' time the company had secured more than 145,000 signatures on its petition "seeking to protect your right to play fantasy sports" and provided a link to sign the petition. ${ }^{134}$

\section{More Traditional Political Techniques}

Finally, regulatory entrepreneurs have also taken advantage of the full range of traditional lobbying techniques that established firms have typically employed. This includes tactics such as putting political operatives on the board of directors or hiring them as key advisers and using professional lobbyists.

Placing political operatives on the board of directors of a company, particularly an early-stage startup company, indicates that regulatory affairs is likely crucial to the business and that changing existing laws or making new laws may be key to the business model. Take, for example, Hyperloop Technologies, a regulatory entrepreneur startup inspired by billionaire technology mogul Elon Musk's idea of a futuristic vacuum-tube transport network that could transport passengers and freight at over 700 miles an hour. ${ }^{135}$ The company was started with the understanding that it would have to change the law or create new law to

\footnotetext{
${ }^{131} \mathrm{Id}$.

132 Nigel Eccles, FanDuel Open Letter (Oct. 2015), http://www.legalsportsreport.com/wpcontent/uploads/2015/10/FanDuel-Regulation-Letter.pdf.

${ }^{133} I d$.

${ }^{134}$ Id. ("We believe smart regulations should be in place, but some lawmakers are seeking to prohibit your right to play fantasy sports as you know it. We need to remind officials how deep and wide the support for fantasy sports is across the country.").

${ }^{135}$ Bruce Upbin, Hyperloop Is Real: Meet the Startups Selling Supersonic Travel, ForBES (Feb. 11, 2015, 6:05 AM), http://www.forbes.com/sites/bruceupbin/2015/02/11/hyperloop-is-real-meetthe-startups-selling-supersonic-travel/\#2715e4857a0b7dd0afd7313c.
} 
support their nascent, never-done-before technology-persuading governments to support futuristic infrastructure, obtaining rights-of-way through cities and across vast distances, and navigating transportation laws written for a different era. The technical challenges involved in developing a hyperloop transportation network are enormous, but the political challenges are equally monumental.

Hyperloop has prepared for political and legal battles by getting influential political operatives involved before those battles have even begun. When the Chief Technology Officer of Hyperloop Technologies first met the company cofounder, he said "I can build the technology-you've got to get me the right of way to do it."136 The co-founder replied, "We've got Jim Messina on our board," referring to the campaign manager for President Obama's 2012 reelection and former White House deputy chief of staff. ${ }^{137}$ In its early stages, the company had also met with major politicians, such as U.S. Senate Democratic leader Harry Reid. ${ }^{138}$ President Obama himself had been briefed on the early-stage startup company and its vision for ultra-high-speed transportation. ${ }^{139}$ The company has also developed a relationship with Eric Garcetti, the mayor of Los Angeles, where the startup is based, who has joked: "I've been part of the marketing department. I talk about it all the time. I've talked to [U.S. Secretary of Transportation Anthony Foxx], the vice president, the president - and they're not paying me a thing!" 140 Many other companies have adopted similar strategies. ${ }^{141}$

Hiring professional lobbyists is another technique that regulatory entrepreneurs use. For example, consider once more electric car manufacturer Tesla Motors. To succeed in its fight against dealer franchise laws, Tesla has had to battle the car dealers lobby and create its own lobbying efforts for state legislative reforms. ${ }^{142}$ The lobbyists that Tesla has hired have been key to its efforts to help win over state legislators. In Texas, for example, Tesla has spent

\footnotetext{
${ }^{136} I d$.

${ }^{137}$ Id. Jim Messina has also worked for Uber and Airbnb. Id.

${ }^{138} \mathrm{Id}$.

${ }^{139} \mathrm{Id}$.

${ }^{140}$ Caroline O’Donovan, Hyping the Hyperloop: How A Moonshot Technology Could Become a Reality, BuzzFEED (Oct. $11, \quad 2015, \quad 7: 01 \quad$ AM), http://www.buzzfeed.com/carolineodonovan/hyping-the-hyperloop-how-elon-musks-dream-couldbecome-a-rea\#.ccRqWaX5k.

${ }^{141}$ Other notable examples of companies involving political strategists in key business positions include Uber (David Plouffe), Airbnb (Chris Lehane), and Theranos (Henry Kissinger; George Shultz; Sam Nunn; Bill Frist). Helderman, supra note 104; Dougherty \& Isaac, supra note 126; Jennifer Reingold, Theranos' Board: Plenty of Political Connections, Little Relevant Expertise, FORTUNE (Oct. 15, 2015, 12:49 PM), http://fortune.com/2015/10/15/theranos-board-leadership/. Regulatory entrepreneurs have also engaged consultants who come through the "revolving door." For example, William Haraf, who had been the Commissioner of the California Department of Financial Institutions, and on whose watch California's money transmission law was implemented, became Managing Director of Promontory Financial Group, a consultancy which advises startups in the virtual currency space. See Greenspan testimony, supra note 91.

${ }^{142}$ Crane, supra note 40.
} 
over half a million dollars on lobbyists in each of the past couple of years. ${ }^{143}$ Tesla hired several notable local lobbyists, including Mike Toomey, a trusted advisor to Governor Rick Perry; Karen Steakley, an ex-deputy legislative director for Governor Rick Perry; Craig Chick, a former senior policy adviser for notable Texas legislators; and Adam Goldman, whose brother is a state lawmaker. ${ }^{144}$ The company started building a coalition of lawmakers and business groups supportive of their cause and hosting legislative staffers at policy forums and company receptions. ${ }^{145}$ These traditional political lobbying techniques have been aimed at helping the company to level the playing field against the powerful car dealer lobby, which has been politically active and generous in making political expenditures for years. ${ }^{146}$ A Tesla vice president explained: "We understood the political equations. We would be stupid not to prepare and equip ourselves to argue effectively in this Legislature."

\section{CONDITIONS THAT Foster REgUlatory ENTREPRENEURSHIP}

In this Part, we use the insights from Part II to identify and consider three basic groups of factors that are particularly important to fostering or discouraging regulatory entrepreneurship. First, we explore factors related to the line of business in question. Second, we consider law-based factors related to the nature of the regulatory uncertainty that the entrepreneur faces. Third, we compare the relative advantages of startup corporations versus more established businesses.

\section{A. Business-Related Factors}

Some lines of business are better suited to a regulatory entrepreneurship model than others. As discussed in Part I, the strategies that modern regulatory entrepreneurs employ to effect legal change require two chief inputs: The traditional methods that corporations have used to exert influence-hiring lobbyists, putting politically connected people on their boards, revolving door hiring practices, and spending money on political advertisements-primarily require money. But perhaps even more important for the newer techniques that regulatory entrepreneurs have been pioneering is a user base that can be mobilized as a political force.

\footnotetext{
${ }^{143}$ Grant Gerke, Tesla Motors Secret Weapon: Thoughts and Lobbying Efforts, TESLARATI (Mar. 16, 2015), http://www.teslarati.com/tesla-motors-secret-weapon-thoughts-lobbying-efforts/; David Saleh Rauf \& Neal Morton, Tesla Gears Up for Texas Lobbying Blitz, SAN ANTONIO EXPRESS NEws (Dec. 18, 2014), http://www.expressnews.com/news/local/article/Tesla-gears-up-for-Texaslobbying-blitz-5967219.php.

${ }^{144}$ Saleh \& Morton, supra note 143.

${ }^{145} \mathrm{Id}$.

${ }^{146}$ See, e.g., Bob Adelmann, Tesla Sales Model Upsetting Traditional Auto Dealers, THE New AMERICAN (Mar. 24, 2104), http://www.thenewamerican.com/economy/markets/item/17906-teslasales-model-upsetting-traditional-auto-dealers ("In the 2011-2012 election cycle, according to the National Institute on Money in State Politics, auto dealers and their employees donated more than $\$ 15$ million to state and local candidates. In that same cycle, Tesla donated \$500.”).

${ }^{147} I d$.
} 
What, then, characterizes businesses with the "right" kind of user base? Such businesses possess three chief characteristics: scalability, connectedness, and mass appeal.

Scalability refers to the business being able to expand its user base quickly and easily. For businesses to successfully mobilize users against a regulatory crackdown, they must have sufficient users to fight back at an early enough point in time. It helps to grow quickly so that regulators, who often move slower than entrepreneurs, are unable to squelch the business before it reaches a critical mass. Many regulatory entrepreneurs employ a guerrilla growth strategy to achieve exactly this result. The success of such a strategy depends on growing quickly, and this cannot be done if expanding one's user base requires customized service or extensive and slow capital investment. For example, an advertising agency's business is not scalable because its service is customized for each client and cannot be standardized. By contrast, a company whose main product is software is easily scalable; the extra cost of adding a new user is negligible.

But while having a large user base is necessary, it is not sufficient. A large user base is of little help if those users are unwilling to act; the company must also be able to mobilize those users. This likely depends on several things. The first is the frequency with which users interact with the company. User interactions are opportunities for the company to inform and activate users; the more interactions, the better the company's prospects. Next is whether the format through which the company interacts with its users makes it easy for the company to send users information. How much information the company has about its users matters as well; the more that the company knows about its users, the more finely it can employ them. For example, legislators are likely to be more responsive to comments received from their own constituents than from voters they do not represent. If the company knows where its users live, it may be able to direct individual users' gestures of support (e-mails, phone calls, signed petitions, etc.) to their particular representatives, amplifying their effect. Finally, how motivated will the company's user base be to act on the company's behalf? This will depend on not only the frequency with which users interact with the company, but also on the significance of those interactions. To the extent that the company taps into feelings of identity or more significant needs, users are likely to be more willing to engage.

In addition, the composition of the company's user base matters. Several studies have examined what drives policy changes in the United States, and two findings are key for regulatory entrepreneurship: First, there is a strong status quo bias; it is hard to change the law. ${ }^{148}$ Second, the chances of changing the law are

${ }^{148}$ See, e.g., Martin Gilens, Inequality and Democratic Responsiveness, 69 PUBLIC OPINION Quarterly 778, 786 (2005); Martin Gilens \& Benjamin I. Page, Testing Theories of American Politics: Elites, Interest Groups, and Average Citizens, 12 PersP. ON POL. 564, 573 (2014). 
greatest when high-earning citizens support the change. ${ }^{149}$ Thus, a user base that contains many affluent users is likely to significantly increase a company's chance of success.

At the same time, however, anecdotal evidence suggests that it is also helpful to have a compelling story to tell. People remember personal stories; putting the right face on an issue is a potent political tool. ${ }^{150}$ Thus, it helps to have a product that also benefits middle- or working-class people, whose stories may be more likely to evoke sympathy and support among viewers, as well as the affluent.

For example, in November 2015, San Francisco was considering Proposition F, an initiative that would have increased restrictions on short-term rentals in San Francisco. In the days leading up to the vote, Airbnb and its supporters blanketed the airwaves with advertisements urging voters to oppose the measure. ${ }^{151}$ A number of ads opposing Proposition $F$ featured the stories of people who frequently rent out various spaces on a short-term basis. ${ }^{152}$ All of these people talked about the difficulties of living in such an expensive city, and most told stories about particular financial needs that short-term renting helped them to manage, such as financially supporting elderly parents ${ }^{153}$ and paying for a two-year-old daughter's childcare. ${ }^{154}$ One ad featured a couple who asserted that home sharing enables them to go volunteer and teach English to Tibetan refugees and impoverished children. ${ }^{155}$

\footnotetext{
${ }^{149}$ See, e.g., Gilens, supra note 148, at 788-89 (using the preferences of Americans at the ninetieth income percentile as a measure of what high-earning citizens prefer); Gilens \& Page, supra note 148 , at 568-70 (similar).

${ }^{150}$ See Ted Brader, CAmpaigning for Hearts and Minds: How Emotional Appeals in POLITICAL ADS WORK (2006).

151 Nancy Watzman, Pro-Airbnb Advertising Dominated Recent Political TV Ads in San ARCHIVE (Nov. 4 , 2015), http://webcache.googleusercontent.com/search?q=cache:UALLU18Mk5IJ:https://blog.archive.org /2015/11/04/pro-airbnb-advertising-dominated-recent-political-tv-ads-in-sanfrancisco/ $+\& \mathrm{~cd}=4 \& \mathrm{hl}=\mathrm{en} \& \mathrm{ct}=\mathrm{clnk} \& \mathrm{gl}=\mathrm{us}$ (finding that anti-proposition $\mathrm{F}$ ads constituted roughly two-thirds of all political TV ads; the ratio of television ad minutes opposing prop $\mathrm{F}$ to those supporting it was over 120:1; the ratio of television ad minutes opposing prop $\mathrm{F}$ to those related to the mayoral race was more than 35:1).

152 SF Against F, Maria Is Renting Out Her Home Office, available at https://archive.org/details/SFElections2015ads; SF Against F, SF Against F, Meet Another SF Tenant Against Proposition F, available at https://www.youtube.com/watch?v=us-8kBlIEv0; Meet Cathryn, Your SF Neighbor, available at https://archive.org/details/SFElections2015ads; SF Against F, Meet Karen, a Neighbor of Homesharers, Who Opposes Proposition F, available at https://www.youtube.com/watch?v=E0ukLPLfdSg; SF Against F, Meet Kate from Glen Park, available at https://archive.org/details/SFElections2015ads; SF Against F, Please Join Ken and Ashish from the Castro; available at https://archive.org/details/SFElections2015ads.

${ }^{153}$ SF Against F, Meet Cathryn, Your SF Neighbor, supra note 152.

${ }^{154}$ SF Against F, Meet Kate from Glen Park, supra note 152.

${ }^{155}$ SF Against F, Please Join Ken and Ashish from the Castro, supra note 152.
} 
Alternatively, Proposition F opponents could have told the story of a wealthy property owner who simply found that short-term rentals were more lucrative than taking on residents as long-term tenants. They presumably chose not to because they concluded that it would be less politically effective. Indeed, this was the story that supporters of Prop F tried to tell in their advertisements. One, entitled "Save the Moguls," cast rich commercial landlords as the face of short-term rentals. ${ }^{156}$ Another had actors play a variety of unsympathetic figures, each of whom gives her reasons for opposing Proposition F. ${ }^{157}$ Many of these reasons are immoral, such as a desire to exclude elderly people from San Francisco and to evict minority tenants. ${ }^{158}$ Others are simply politically unpersuasive: A character talked about how short-term rental of his extra room had enabled him to fund his artisanal relish production. ${ }^{159}$ Another was determined to protect Airbnb's profits at all costs. ${ }^{160}$ One character opposed Proposition F simply because he liked Airbnb's logo. ${ }^{161}$

Airbnb won its battle against Proposition F, as voters rejected it by a 10point margin. Other companies have successfully employed similar tactics in their political battles. To take another example, during Uber's battle for New York, it ran advertisements in which Uber drivers highlighted how becoming an Uber driver had improved their lives. ${ }^{162}$ They spoke about how their pre-Uber lives were characterized by difficulties finding jobs, being unable to pay their mortgages, and struggling to make ends meet. ${ }^{163}$ One said that becoming an Uber driver "was probably the best thing that's happened in [his] life." 164 Another described it as "a blessing ... We don't just pick people up. We pick ourselves up. We pick our families up." 165 It asserted that Uber would create 10,000 jobs in New York City over the next year, and urged voters to tell mayor de Blasio, who had received significant donations from the taxi industry, "Don't put taxi donors ahead of jobs." 166 The advertisement closed with an Uber driver saying "millionaire [cab] medallion owners don't need help. People like us do."167

\footnotetext{
${ }^{156}$ Sharebetter, "Save the Moguls", available at https://archive.org/details/SFElections2015ads.

${ }^{157}$ Broke $\left.{ }^{*}\right]$ Stuart, [*] Against Prop F, available at https://archive.org/details/SFElections2015ads. ${ }^{158} \mathrm{Id}$.

${ }^{159} I d$.

${ }^{160} \mathrm{Id}$.

${ }^{161} \mathrm{Id}$.

162 Uber, Mayor de Blasio's Proposal Will Destroy 10,000 Jobs, available at https://www.youtube.com/watch? $v=x F O Q 6 I D 61 v k \&$ feature=youtu.be; Uber, Killing 100,000 NYC Jobs, With One Taxi-Backed Bill (June 30, 2015), https://newsroom.uber.com/us-newyork/killing-10000-nyc-jobs-with-one-taxi-backed-bill/; see also Dan Rivoli, Uber Slams Mayor de Blasio with TV Ad Claiming He's 'Giving in to the Taxi Industry', N.Y. DAILY News (July 16, 2015), http://www.nydailynews.com/news/politics/uber-slams-mayor-de-blasio-tv-ad-article1.2293201.

${ }^{163}$ Uber, Mayor de Blasio's Proposal, supra note 162.

${ }^{164} \mathrm{Id}$.

${ }^{165} I d$.

${ }^{166} I d$.

${ }^{167}$ Id.; see also Alan Feuer, Uber Drivers Up Against the App, N.Y. TIMES (Feb. 19, 2016), http://www.nytimes.com/2016/02/21/nyregion/uber-drivers-up-against-the-app.html ("Uber mobilized millions of dollars and an all-star team of political tacticians, but it also made use of the
} 
These business-related factors help explain why regulatory entrepreneurship has increased so much in recent years. Many of the most successful startup companies in the last few years are "platform" companies. ${ }^{168}$ These businesses profit by using technology to connect buyers and sellers on a proprietary platform. Examples include Uber, Lyft, Airbnb, and others. ${ }^{169}$

Platform business models are enormously scalable; if new users wish to join the system, they can be added quickly and easily. Moreover, since these businesses are built around the platform, these companies are well-equipped to communicate with their users. Depending on the product and user in question, the user's level of commitment to the company can be quite large. For example, an Uber driver or an Airbnb landlord - or a provider on a lesser-known platform, such as zTailors, the "Uber for tailors"- may reap hundreds or even thousands of dollars a week via their interaction with the app. ${ }^{170}$ In addition, in many instances the regulatory entrepreneur will have a great deal of information about the user, such as where she lives and how much she uses the entrepreneur's product, that may potentially allow the entrepreneur to leverage that user more effectively. ${ }^{171}$

Finally, the most successful of these businesses appeal to both those with high incomes and those of more modest means. New York Uber users include high earners willing to pay extra to get a ride home immediately at the end of a rainy night out, middle-class outer borough residents who have trouble finding cabs in their neighborhoods, and Uber drivers who might face serious hardships

sympathetic image of hard-working immigrants telling City Hall that Uber put food on the table for their families.").

168 See Orly Lobel, The Law of the Platform 7-8, 12-13, (manuscript on file with authors) (explaining the definition of platform companies and listing over two dozen); Daniel E. Rauch \& David Schleicher, Like Uber, But for Local Government Law: The Future of Local Regulation of the Sharing Economy, 76 OHIO ST. L.J. 901 (2015) (discussing various sharing economy peer-topeer platform companies); Fortune, The Unicorn List, available at http://fortune.com/unicorns/ (last visited Jan. 29, 2016) (listing startup companies valued at $\$ 1$ billion or more and including platform companies such as Uber, Airbnb, Lyft, BlaBlaCar, FanDuel, and DraftKings).

${ }^{169}$ Fortune, The Unicorn List, supra note 168.

${ }^{170}$ See, e.g., Rachel Gillett, Here's How Much You Could Make As an Uber or Lyft Driver in 20 Major U.S. Cities, BUSINESS INSIDER (July 20, 2015, 11:40 AM), http://www.businessinsider.com/how-much-uber-drivers-make-in-each-city-2015-7; Sarah Kessler, Secrets of Running A Six-Figure AirBnB Business, Fast Company (Nov. 5, 2013, 1:25 PM), http://www.fastcompany.com/3021179/secrets-of-running-a-six-figure-airbnb-business; Davey Alba, Instacart Shoppers Can Now Choose To Be Real Employees, WIRED (June 22, 2015, 5:46 PM), http://www.wired.com/2015/06/instacart-shoppers-can-now-choose-real-employees/; Derek Thompson, The Uber Economy, ATLANTIC (Jan. 23, 2015), http://www.theatlantic.com/business/archive/2015/01/is-uber-a-middle-class-job-creator-ornot $/ 384763 /$.

${ }^{171}$ See Nancy Scola \& Andrea Peterson, Data Is Uber's Business. But Protecting It May Be Its Biggest Weakness., WASH. POST (Nov. 18, 2014), https://www.washingtonpost.com/news/theswitch/wp/2014/11/18/data-is-ubers-business-but-protecting-it-may-be-its-largest-weakness/. 
without the income they earn through Uber. ${ }^{172}$ Airbnb landlords include those who need to rent out rooms to guests in order to cover the cost of their housing, as well as well-off people who buy investment properties and rent them for profit. ${ }^{173}$ These types of broad user bases can maximize a company's chance of political success.

\section{B. Law-Related Factors}

The chance of successfully executing a regulatory entrepreneurship strategy depends on a number of factors related to the law in question. These relate to the kind and magnitude of regulatory uncertainty that the entrepreneur is taking on.

One important factor is the penalty that the law imposes on violators. For example, if the only penalty is a civil fine imposed on the corporation, pushing the boundaries of the law may be an attractive prospect. If the fine is low enough, the business may not even have to worry about changing the law and can simply pay fines as they come up. ${ }^{174}$

On the other hand, if a law provides for the incarceration of the executives of a company that violates it, that is likely to serve as a serious deterrent to the guerrilla growth strategies that modern regulatory entrepreneurs employ. For instance, in some states, operating an unlicensed money transfer business is a felony punishable by imprisonment and a criminal fine; ${ }^{175}$ this has tamped down on mobile payment companies' willingness to push the boundaries of the licensing regimes they face. ${ }^{176}$

Another key element is whether the law in question is determined at the local, state, or national level. Change at the state and local level is often possible more quickly than at the national level. This is largely by design; the framers wanted to ensure that state governments remained important centers of power and served as laboratories of democracy and reform. ${ }^{177}$ The faster pace at which change is usually possible at the state and local levels makes regulatory

172 See Carolyn Said, Airbnb, Uber Cast Themselves As Saviors of the Middle Class, S.F. CHRONICLE (Nov. 10, 2015, 8:16 PM), http://www.sfchronicle.com/business/article/Airbnb-UberWe-are-the-saviors-of-the-middle-6620729.php

${ }^{173}$ See Adam Chandler, Is AirBnB a Credible Champion on Income Inequality?, ATLANTIC (Dec. 1, 2015), http://www.theatlantic.com/business/archive/2015/12/airbnb-new-york/418272/; Kessler, supra note 170; Said, supra note 172;.

${ }^{174}$ Uber has operated by paying drivers' fines in Paris, though this appears to be a temporary measure. Alderman, supra note 87.

${ }^{175}$ See Kevin V. Tu, Regulating the New Cashless World, 65 ALA. L. Rev. 77, 79-98, n.101 (2013) (examining the legal and regulatory landscape affecting emerging payment systems).

${ }^{176}$ See id. at 109-13; Scheiber, supra note 91.

${ }^{177}$ See New State Ice Co. v. Liebman, 285 U.S. 262, 311 (1932) (Brandeis, J., dissenting) ("It is one of the happy incidents of the federal system that a single courageous state may, if its citizens choose, serve as a laboratory; and try novel social and economic experiments without risk to the rest of the country."). 
entrepreneurship more feasible within the "runway" of capital, or timeline, the company has to operate. ${ }^{178}$

Further, state and local political fights generally attract much smaller amounts of resources than national fights do. ${ }^{179}$ It takes less money to make waves in state and local politics; at the national level, even a significant amount of money can be lost as a drop in the bucket. For example, consider the 2013 mayoral race in New York City, the nation's largest and wealthiest city. Two months before the election, the New York Times reported that in the course of the campaign the candidates had mustered a combined total of approximately $\$ 35$ million and spent about \$30 million. ${ }^{180}$ In the 2014 New York gubernatorial campaign, the candidates spent a combined total of approximately $\$ 55$ million. ${ }^{181}$ In the 2012 Presidential campaign, President Barack Obama and Mitt Romney's campaigns raised and spent roughly a billion dollars each; ${ }^{182}$ spending on all federal elections in 2012 totaled approximately $\$ 7$ billion. ${ }^{183}$ Spending enough money to have a significant effect at that level can be prohibitively expensive. ${ }^{184}$

178 See John F. Coyle \& Joseph M. Green, Contractual Innovation in Venture Capital, 66 HASTINGS L.J. 133, 151 (2014) (noting that startup companies typically refer to the "runway" of capital they have raised for a certain period of operations).

179 See The Money Behind the Elections, OpenSecrets.org, available at https://www.opensecrets.org/bigpicture/ (last visited Feb. 1, 2016) (showing that the costs of federal congressional and presidential races in recent years have been in the billions versus state contributions each significantly less).

${ }^{180}$ How Much the N.Y.C. Mayoral Candidates Have Raised and Spent, N.Y. TIMES (Sept. 2, 2013), http://www.nytimes.com/interactive/2013/03/16/nyregion/how-much-the-nyc-mayoralcandidates-have-raised-and-spent.html?_r=0. These totals included potential candidates who had not officially declared their candidacies, as well as money that a candidate borrowed or transferred from another campaign. Id.

181 New York Gubernatorial and Lieutenant Gubernatorial Election, 2014, BALLOTPEDIA, https://ballotpedia.org/New_York_gubernatorial_and_lieutenant_gubernatorial_election.

${ }_{182}$ The 2012 Money Race: Compare the Candidates, N.Y. TIMES, http:/elections.nytimes.com/2012/campaign-finance. These numbers include amounts raised by the candidates, the national party committees, and each candidate's chief Super PAC, but not other PACS or each candidate's victory fund. $I d$.

183 Tarini Parti, FEC: \$7B Spent on 2012 Campaign, Politico (Jan. 31, 2013), http://www.politico.com/story/2013/01/7-billion-spent-on-2012-campaign-fec-says-087051.

${ }^{184}$ It is also worth noting that there are limits to what money can accomplish politically. Some economists have argued that campaign spending is much less influential than the conventional wisdom would dictate, and some donors have lamented that they are unable to buy more influence. See, e.g., Stephen J. Dubner, How Much Does Campaign Spending influence the Election? A Freakonomics Quorum, FREAKONOMICS (Jan. 17, 2012), http://freakonomics.com/2012/01/17/how-much-does-campaign-spending-influence-the-electiona-freakonomics-quorum/; Eliza Collins, Charles Koch Bemoans Lack of Influence Over 2016 Race, Politico (Jan. 8, 2016), http://www.politico.com/story/2016/01/charles-koch-2016presidential-race-217499\#.chuesce:A0Og; Matthew Cooper, Koch Brothers Money Hasn't Bought As Much As You Think, NewsweEK (Apr. 24, 2014), http://www.newsweek.com/2014/05/02/kochbrothers-money-hasnt-bought-much-you-think-248390.html. On the other hand, money clearly has some impact on elections and donors must have some reason for making the contributions that they do. 
Another advantage of targeting state or local laws is the added flexibility. The large number of state and local jurisdictions enables companies to pick their battles in ways that increase their chances of success over time. The entrepreneur can start with the jurisdictions that it finds most promising, or hold off on targeting a particular location of interest until conditions are favorable. The entrepreneur has a real option; it can adjust its actions in response to changing conditions. It can decide to abandon a particular strategy, delay, or expand. Moreover, the entrepreneur does not have to win every battle to achieve some measure of success. ${ }^{185}$ These options are generally not available when the law in question is national.

Further, flexibility is useful because political environments fluctuate over time, and changing political headwinds can make it easier or harder to exert influence and alter the law. These fluctuations are driven by economic and social conditions that are generally difficult or impossible to deliberately influence. Similarly, politicians rise and fall. An entrepreneur may benefit from the popular strength of a sympathetic official, or the weakness of an antagonistic one. For instance, in 2009, billionaire Michael Bloomberg spent \$102 million of his own money to help finance his successful mayoral campaign. ${ }^{186}$ Non-billionaire Bill de Blasio spent about one tenth of that during his successful campaign four years later. ${ }^{187}$ If an entrepreneur were looking to use its money to pressure the mayor's office, it might well find that its chances were much better during the latter's time in office. Conversely, if the mayor's office favored the entrepreneur's proposed change, acting earlier might have been preferable.

There are also tactics available at the state and local level that are not available at the national level. For example, in 2014, Uber wanted to open in Portland, but faced opposition from the city government. ${ }^{188}$ In response, Uber began offering service in Vancouver, Washington, which is a stone's throw away from Portland, then sent the message "Hey Portland, we are just across the river . .

${ }^{185}$ DraftKings and FanDuel are an example of this approach. According to one source:

[They] have chosen which states to operate in based on the individual rules in that state, which vary. . . As recently as October, the two companies were operable in 45 states-in the other five, they had chosen not to operate because the law appeared unfriendly. Very recently, that number has gone to 44 after Nevada's Gaming Control Board ruled these companies gambling operators. It now threatens to go down to 43 because of New York.

Daniel Roberts, FanDuel, DraftKings File Lawsuits Against NY Attorney General, ForTUNE (Nov. 13, 2015), http://fortune.com/2015/11/13/fanduel-draftkings-lawsuits-schneiderman/.

${ }^{186}$ Celeste Katz, Mayor Bloomberg Spent $\$ 102 M$ on Campaign to Win Third Term - or $\$ 175$ Per Vote, N.Y. DAILY NeWS (Nov. 27, 2009), http://www.nydailynews.com/new-york/mayorbloomberg-spent-102m-campaign-win-term-175-vote-article-1.414005.

187 See Michael Howard Saul, Here's How Much Money is in the Mayor's New Campaign Account, Wall ST. J. (July 9, 2014), http://blogs.wsj.com/metropolis/2014/07/09/heres-howmuch-money-is-in-the-mayors-new-campaign-account/ (noting de Blasio "raised roughly $\$ 10.7$ million, received nearly $\$ 4$ million in public funds and spent about \$13.6 million").

${ }^{188}$ Weise, supra note 30. 
.."189 Uber proceeded to begin offering service in several adjacent suburbs of Portland. ${ }^{190}$ As Portland's mayor described the experience, "They basically forced their way into the market and surrounded us, then put the pressure on for us to do likewise." ${ }^{\text {S191 }}$ Strategies such as that, which rely on geographic proximity, are less likely to work well when applied at the national level; it seems harder to imagine a company pushing through a legal change in the United States on the grounds that Canada and Mexico both adopted it.

And, because regulatory entrepreneurship is a form of politicking, it is better-suited to the more political branches of government. An army of users is more likely to be a compelling tool against executive and legislative bodies than judicial ones. Judges are particularly unlikely to be swayed by popular opinion if their terms are longer and if they are appointed instead of elected. ${ }^{192}$ This further advantages state battles over federal ones; in many states and cities, judges are elected, while judges in federal district and appellate courts are appointed for life. ${ }^{193}$ On the other hand, when a company finds itself in court, the longer that it can drag out the proceeding, the more time it may have to grow its user base and lobbying arm and push for a legal change.

For example, DraftKings and FanDuel had been operating in the shadow of the law, each spending more than $\$ 100$ million on television advertising and signing up tens of thousands of users each day, before receiving a cease-anddesist order from the New York state attorney general. ${ }^{194}$ The attorney general wrote: "It is clear that DraftKings and FanDuel are the leaders of a massive, multi-billion dollar scheme intended to evade the law and fleece sports fans across the country." ${ }^{195}$ Both companies continue to operate, attempting to rally users to support their legal cause, and have each filed lawsuits seeking an injunction

189 Id.; Uber, Hey Portland, We Are Just Across the River... \#WeWantUberPDX, UBER NEWSROOM, July 18, 2014, https://newsroom.uber.com/pdx/hey-portland-we-are-just-across-theriver-wewantuberpdx/.

${ }^{190}$ Weise, supra note 30.

${ }^{191} I d$.

${ }^{192}$ See Judith Resnik, Judicial Independence and Article III: Too Little and Too Much, 72 S. CAL. L. REV. 657, 666 (1999); Shirley S. Abrahamson, Thorny Issues and Slippery Slopes: Perspectives on Judicial Independence, 64 OHIO ST. L.J. 3, 9 (2003) ("In exercising judicial independence, the stakes for the judges, that is, the loss of the judgeship, are clearly higher for judges with limited terms than they are for appointed judges with life tenure.").

${ }^{193}$ See David E. Pozen, The Irony of Judicial Elections, 108 Colum. L. Rev. 265 (2008) (examining "elective versus nonelective judiciaries").

${ }^{194}$ Walt Bogdanich et al., Attorney General Tells DraftKings and FanDuel to Stop Taking Entries in New York, N.Y. TIMES (Nov. 10, 2015), http://www.nytimes.com/2015/11/11/sports/football/draftkings-fanduel-new-york-attorneygeneral-tells-fantasy-sites-to-stop-taking-bets-in-new-york.html.

195 State of New York Office of the Attorney General. Notice to Cease and Desist and Notice of Proposed Litigation Pursuant to New York Executive Law § 63(12) and General Business Law $\$ \quad 349 \quad$ (Nov. 10,2015 ), http://www.nytimes.com/interactive/2015/11/10/sports/document-final-nyag-fanduel-letter-11-102015-signed.html. 
against the cease-and-desist order. ${ }^{196}$ DraftKings retained the same high-profile lawyer who represented Al Gore in the 2000 presidential election. ${ }^{197}$ The company filed a petition against the attorney general, seeking to stop him "from carrying out his threat to banish from this State a lawful industry beloved by hundreds of thousands of New Yorkers."198 FanDuel has taken a similar approach. The legal battles may drag on for significant periods of time, while they continue to grow and encounter battles in other states. ${ }^{199}$

Many of the highest-profile companies that attempted a regulatory entrepreneurship strategy and failed did so because they found themselves fighting national laws in federal courts. One of the most famous examples was Napster, the peer-to-peer file sharing program. ${ }^{200}$ Many of the files shared on Napster were copyrighted works, and the Recording Industry Association of America ultimately sued Napster in federal court for contributory and vicarious infringement of copyright. ${ }^{201}$ The suit brought Napster publicity and further grew its user base, but this did not help Napster when it lost in court. ${ }^{202}$ Napster was eventually forced into bankruptcy. ${ }^{203}$ Other companies in the same space have encountered similar problems, including Grokster, Kazaa, MusicCity, and Limewire. $^{204}$

More recently, Aereo lost a high-profile Supreme Court case regarding the legality of its business. ${ }^{205}$ Aereo's business model was based on making television content that networks broadcast over the airways available to subscribers via streaming over the Internet. ${ }^{206}$ This raised questions of copyright infringement. $^{207}$ Aereo attempted to lobby the FCC and Congress for changes in the relevant laws and regulations, both before and after it lost in court, but ultimately failed and had to enter bankruptcy. ${ }^{208}$

\footnotetext{
${ }^{196}$ Roberts, supra note 185.

${ }^{197} \mathrm{Id}$.

${ }^{198} \mathrm{Id}$.

199 Id.; see also Davey Alba, Now Texas Says DraftKings and FanDuel are Gambling, WIRED (Jan. 19, 2016), http://www.wired.com/2016/01/now-texas-says-draftkings-and-fanduel-aregambling/ (noting legal battles for the companies in states other than New York).

${ }^{200}$ See Jonathan Zittrain, A History of Online Gatekeeping, 19 HARV. J.L. \& TECH. 253, 273-76 (2006) (recounting Napster's history).

${ }^{201}$ See A\&M Records, Inc. v. Napster, Inc., 114 F. Supp. 2d 896 (N.D. Cal. 2000), aff'd in part, reversed in part, 239 F.3d 1004 (9th Cir. 2001).

${ }^{202}$ A\&M Records, Inc. v. Napster, Inc., 239 F.3d 1004 (9th Cir. 2001).

${ }^{203}$ In re Napster Copyright Litig., Nos. C MDL 00-1369 MHP, 2006 WL 1348555 (May 17, 2006).

${ }^{204}$ Zittrain, supra note 200, at 286-93.

${ }^{205}$ Am. Broad. Cos., Inc. v. Aereo, Inc., 573 U.S. _, 134 S. Ct. 2498 (2014).

${ }^{206}$ Dan Burk, Inventing Around Copyright, 109 Nw. U. L. REV. 547, 548-51 (2015) (describing Aereo's technology).

207 See id.

${ }^{208}$ See In re Aereo, Inc., No. 14-13200-2hl, 2014 WL 7721237 (Bankr. S.D.N.Y. 2014); see also Katy Bachman, Rockefeller Wants to Give Online Video Services Parity with Cable, AD WEEK, Nov. 12, 2013, http://www.adweek.com/news/technology/rockefeller-wants-give-online-videoservices-parity-cable-153795; Brian Fung, Aereo to the FCC: Let Us Join the Cable Companies
} 
Of course, there have been some regulatory entrepreneurs who have succeeded with regulatory entrepreneurship strategies in federal court. In the early days of videocassette recorders (VCRs), it was unclear whether their use on copyrighted programming constituted copyright infringement. ${ }^{209}$ If so, the manufacturers were potentially liable and the business model would not have been viable. $^{210}$ However, the VCR manufacturers successfully won at the Supreme Court, saving the business. ${ }^{211}$

The early days of Federal Express provide another good example of a company making its business viable by changing the law at the federal level. ${ }^{212}$ Federal Express was founded in 1971, and in 1976 it began lobbying hard for the deregulation of air cargo transport. ${ }^{213}$ It succeeded in 1977-a very rapid turnaround for a change in federal law. ${ }^{214}$ But in some ways, this is the example that proves the rule, as a number of factors came together in ways that Federal Express could neither have controlled nor predicted. First, Flying Tiger Line, Federal Express's largest competitor, completely changed its position on the existing statutory regime and joined Federal Express in pushing for deregulation. $^{215}$ This was especially notable because the chair of the House Subcommittee on Aviation, which had killed Federal Express's prior attempts to change the law, represented the district in which Flying Tiger's headquarters were located. $^{216}$ Second, Federal Express benefited from a number of useful allies-in particular Alfred Kahn, the Chair of the regulatory body charged with overseeing Federal Express. ${ }^{217}$ This confluence of factors is rare, and generally beyond the control of the regulatory entrepreneur.

\footnotetext{
We Tried to Replace, WASHINGTON Post (Oct. 12, 2014), https://www.washingtonpost.com/news/the-switch/wp/2014/10/13/aereo-to-the-fcc-let-us-join-thecable-companies-we-tried-to-replace/.

209 See Jessica Litman, Campbell at 21/Sony at 31, 90 WASH. L. REV. 651, 666-67 (2015) (describing how even after oral argument in Sony, the majority of Supreme Court justices were initially inclined to affirm the Ninth Circuit's copyright infringement ruling).

${ }^{210}$ See id. at 664 (noting that Sony "was making a significant amount of money selling devices designed to copy copyrighted television programs" and describing this as "the trumpet problem" of "making money because of works written by others"); see also JAMES LARDNER, FAST FORWARD (2002).

${ }^{211}$ Sony Corp. of America v. Universal City Studios, Inc., 464 U.S. 417 (1984).

212 This is perhaps a border case of regulatory entrepreneurship. Fed Ex was not started, nor did it begin cargo delivery, planning to or thinking that it needed to change the law. Instead, after its strategy of navigating the existing regulations failed, it later decided that it needed to change the law to be viable, and succeeded in doing so. For an excellent discussion of the FedEx case, see Jill E. Fisch, How Do Corporations Play Politics?: The FedEx Story, 58 VAND. L. REV. 1495 (2005).

${ }^{213} I d$. at $1503-05,1512-15$.

${ }^{214} \mathrm{Id}$. at 1515.

${ }^{215} \mathrm{Id}$. at $1514-16$.

${ }^{216} \mathrm{Id}$. at 1514 .

${ }^{217} \mathrm{Id}$. at 1513 .
} 


\section{The Prevalence of Startups as Regulatory Entrepreneurs}

Finally, in addition to the general business and law-related factors at play, it seems significant, and not random, that startup companies seem to represent a disproportionately large share of regulatory entrepreneurs. There are several reasons for startups' relative prevalence or edge over more established businesses in the area of regulatory entrepreneurship.

First, by their nature regulatory entrepreneurs are innovators. A large body of literature examines startups and established companies' relative merits at fostering innovation and new technologies. ${ }^{218}$ There may be a historical aspect to this narrative of innovation, as before 1980, fewer than 200 very large and established corporations accounted for most R\&D in the United States. ${ }^{219}$ But since 1980, the growth in private R\&D in the U.S. economy is attributable to relatively small and new companies. ${ }^{220}$

Second, as discussed in Part I, "guerilla growth" is one of the key tactics that regulatory entrepreneurs have deployed. When deployed successfully, companies become "too big to ban" before regulators can crack down. The regulators' timeline is difficult for an entrepreneur to control. Thus, the success of this strategy hinges on the entrepreneur's ability to enter a market and grow as quickly as possible.

Silicon Valley startups are known for trying to grow their user base as quickly as possible and to worry about making money later. ${ }^{221}$ For years, startups

${ }^{218}$ See, e.g., Joshua Lerner, Small Businesses, Innovation, and Public Policy, in ARE SMAll FIRMS IMPORTANT? THEIR ROLE AND IMPACT (Zoltan J. Acs ed., 1999); ClAYTON M. CHRISTENSEN, THE Innovator's Dilemma: When New Technologies Cause Great Firms to Fail 45 (1997); Avishalom Tor, The Fable of Entry: Bounded Rationality, Market Discipline, and Legal Policy, 101 Mich. L. ReV. 482 (2002); Christopher Freeman, The Economics of Industrial INNOVATION 135-37 (2d ed. 1982); Zoltan J. Acs \& Audretsch, Innovation in Large and Small Firms: An Empircal Analaysis, 78 AM. ECON. Rev. 678 (1988); Charles P. Himmelberg \& Bruce C. Petersen, R\&D and Internal Finance: A Panel Study of Small Firms in High-Tech Industries, 76 ReV. ECOn. \& StAT. 38 (1994); Janet E. L. Bercovitz et al., Firm Capabilities and Managerial Decision Making: A Theory in Innovation Biases, in TeCHNOLOGICAL InNOVATION: OversightS AND Foresights (Raghu Garud et al. eds., 1997); but see Richard J. Pierce, Jr., Small Is Not Beautiful: The Case Against Special Regulatory Treatment of Small Firms, 50 ADMIN. L.R. 537, 551-52 (1998) (finding that numerous studies of innovation and small business are inconclusive).

219 Robert M. Hunt \& Leonard I. Nakamura, The Democratization of U.S. Research and Development after 1980, at 8-9, fig.2 (Soc'y for Econ. Dynamics, Working Paper No. 121, 2006), available at http:// www.repec.org/sed2006/up.12143.1138646305.pdf.

${ }^{220}$ Id. at 9; see also Michael J. Meurer, Inventors, Entrepreneurs, and Intellectual Property Law, 45 Hous. L. REV. 1201, 1202 (2008).

${ }^{221}$ E.g., Matthew Braga, Twitter's Road to IPO: Grow First, Monetize Later, Fin. Post (Sept. 13, 2013), http://business.financialpost.com/fp-tech-desk/twitters-road-to-ipo-grow-first-monetizelater?_lsa $=61 \mathrm{db}-\mathrm{bf2c}$ (discussing companies like Twitter, Facebook, Dropbox, and Pinterest that had a "grow first, monetize later" philosophy); Nitasha Tiku, Look At How Quickly the Values of Multi-Billion-Dollar Startups Have Multiplied, THE Verge (Feb. 20, 2015), http://www.theverge.com/2015/2/20/8075053/look-at-how-quickly-the-value-of-multi-billion-

dollar-startups-have ("Build momentum now, figure out how to make money later-otherwise, 
have been entering businesses that did not have well-established precedents. It was not always clear what the best way would be for these businesses to monetize their user base. However, the industry consensus was that (1) it would be possible to monetize the user base - that is, the business would be profitable, one way or another-and (2) more users were essential to the company's long-term value. A list of examples in this vein comes quickly to mind, such as YouTube, ${ }^{222}$ Facebook, Twitter, and Instagram. ${ }^{223}$ This created an environment in which industry executives prioritized rapid growth and users over profits. ${ }^{224}$ Over time, this produced an increased focus on how to achieve rapid growth, which in turn led to the development of people with expertise in how to accomplish this goal.

By and large, many of these companies have become viewed as big success stories. ${ }^{225}$ These successes have been supported by an ecosystem of

you'll miss out on the next near-mythic exit."); Sarah Frier \& Eric Newcomer, The Fuzzy, Insane Math That's Creating So Many Billion-Dollar Tech Companies, Bloomberg (Mar. 17, 2015), http://www.bloomberg.com/news/articles/2015-03-17/the-fuzzy-insane-math-that-s-creating-somany-billion-dollar-tech-companies (noting how startup investors look to the number of users in valuing the company and "salivate over what's called 'hockey-stick' growth curves, indicating massive uptake").

${ }^{222}$ E.g., Nicholas Jackson, Infographic: The History of Video Advertising on YouTube, ATLANTIC (Aug. 3, 2011), http://www.theatlantic.com/technology/archive/2011/08/infographic-the-historyof-video-advertising-on-youtube/242836/; Rolfe Winkler, YouTube: 1 Billion Viewers, No Profit, WALL ST. J. (Feb. 25, 2015), http://www.wsj.com/articles/viewers-dont-add-up-to-profit-foryoutube-1424897967.

${ }^{223}$ See David Holmes, Social Sites Have Found a New Monetization Strategy and It Leaves Indie Creators Out in the Cold, PANDO (Feb. 13, 2015), https://pando.com/2015/02/13/social-sites-havefound-a-new-monetization-strategy-and-it-leaves-indie-creators-out-in-the-cold/ (discussing the history of monetizing online technology); Braga, supra note 221.

${ }^{224}$ See Frier \& Newcomer, supra note 221 (noting that a "tech startup's cash flow is less important than you might think" but investors "look to find the number of people using the product, regardless of whether they pay for it"); Claire Cain Miller, Popularity or Income? Two Sites Fight It Out, N.Y. TIMES (Oct. 20, 2008), http://www.nytimes.com/2008/10/21/technology/startups/21twitter.html? r=1\&hp (discussing several high profile tech startups that succeeded with a strategy of prioritizing user growth rather than profits); Dan Primack, Tech IPOs: Profits Don't Matter, FORTUNE (Mar. 26, 2014), http://fortune.com/2014/03/26/tech-ipos-profits-dont-matter/ (noting that "profits don't really matter when it comes to tech IPOs" and "[t]oday's IPO buyers care about two key metrics: (1) Growth. (2) Total available market, into which that growth can be realized."); Eric Kutcher et al., Grow Fast or Die Slow, MCKInSEY \& Co. (April 2014), http://www.mckinsey.com/industries/high-tech/our-insights/grow-fast-or-die-slow ("Growth trumps all.”).

${ }^{225}$ Either because they succeeded in becoming profitable, were purchased by other companies at large valuations, or conducted successful initial public offerings. See, e.g., Miller, supra note 224 ("Successes like YouTube, the online video site sold to Google for $\$ 1.65$ billion in 2006, convinced some venture investors that building a Web site with a large number of users could still be more valuable than making money from paying customers."); Larry Popelka, What We Learned From Twitter's IPO: The Value of Innovation Is at an All-Time High, BLOOMBERG (Nov. 18, 2013), http://www.bloomberg.com/bw/articles/2013-11-18/what-we-learned-from-twitter-s-ipothe-value-of-innovation-is-at-an-all-time-high (noting that Twitter had a successful IPO, becoming one of the most valuable companies in the world at a $\$ 25 \mathrm{~B}$ valuation based not on profit but on the value of its great innovation). 
investors who are willing to accept large amounts of risk and uncertainty, ${ }^{226}$ support growth-focused strategies, and take a long-term view. Angel investors, many of whom are successful ex-entrepreneurs, and the venture capital market make early-stage financing feasible for high-risk, high-return businesses. ${ }^{227}$ Most angel investors like being involved in exciting new ventures, and view the potential to disrupt entire industries as an added bonus. ${ }^{228}$ Thus, startup investors are willing to take the long view of companies' business prospects, even those companies that have never operated profitably. For example, although neither DraftKings nor FanDuel has yet proven profitable, each startup company is already valued at close to $\$ 1$ billion. ${ }^{229}$ Airbnb, valued at almost $\$ 25$ billion, forecasts that its business will lose $\$ 150$ million in 2015 , and that it will not be profitable (even excluding interest, taxes, depreciation, and amortization) until 2020 . $^{230}$ Uber, whose valuation of over $\$ 60$ billion makes it the world's most valuable private startup, loses "boatloads of money," reporting net operating losses of $\$ 470$ million on $\$ 410$ million in revenues. ${ }^{231}$

In contrast, established businesses and their investors tend to operate on more well-trodden ground. For example, coal mining is an old business with a long track record. There are clearer expectations for how a coal mine will make its money-it is going to sell coal. There are many other coal mining companies, and previous years of the company's own operating results, to compare the company's performance against. It is easier to evaluate how well the business is performing, and it is harder for an established company to argue that big, positive changes are looming on the horizon.

\footnotetext{
${ }^{226}$ Legal risks are just one of many types of bet-the-company risks that startup companies may be facing, and often is not even identified as one of the top risks in startup companies. See Sreekanth Ravi, When Launching Your Startup, Consider These 5 Risks, ENTREPRENEUR (May 21, 2014), http://www.entrepreneur.com/article/234094 (discussing product risk, market risk, financial risk, team risk, and execution risk); Thomas Oppong, The 10 Biggest Risks That Prevent VCs From Funding Your Startup, All TOP STARTUPS (Aug. 27, 2014), http://alltopstartups.com/2014/08/27/biggest-startup-risks/ (noting venture capitalist Marc Andreessen listed the following as risks that will cause potential investors to decide not to invest: founder risk, market risk, competition risk, timing risk, financing risk, marketing risk, technology risk, product risk, hiring risk, and location risk).

${ }^{227}$ Ronald J. Gilson, Engineering a Venture Capital Market: Lessons From the American Experience, 55 Stan. L. Rev. 1067, 1068-69 (2003); Darian M. Ibrahim, The (Not So) Puzzling Behavior of Angel Investors, 61 VAND. L. REV. 1405 (2008).

${ }^{228}$ See Ibrahim, supra note 227, at 1412, 1419.

229 Robert Klemko, How Daily Fantasy Is Changing the Game, MMQB (Oct. 8, 2105), http://mmqb.si.com/mmqb/2015/10/08/fanduel-draftkings-scandal-daily-fantasy-football-dfs.

${ }^{230}$ Rolfe Winkler \& Douglas MacMillan, The Secret Math of Airbnb's \$24 Billion Valuation, WALL ST. J. (June 17, 2015), http://www.wsj.com/articles/the-secret-math-of-airbnbs-24-billionvaluation-1434568517.

${ }^{231}$ Biz Carson, Uber Is Reportedly Losing Boatloads of Money, Business Insider (June 29, 2015), http://www.businessinsider.com/uber-reportedly-operating-at-a-470-million-loss-2015-6; Eric Newcomer \& Jing Cao, Uber Bonds Term Sheet Reveals $\$ 470$ Million in Operating Losses, BLOOMBERG BUSINESS (June 29, 2015), http://www.bloomberg.com/news/articles/2015-0630/uber-bonds-term-sheet-reveals-470-million-in-operating-losses.
} 
Similarly, endeavoring to change the law is jeopardous. Politics is a complicated arena with many competing interest groups and sources of uncertainty. It is difficult to predict whether an attempt to change the law will succeed, or what unintended consequences it might produce, on the legal system or otherwise. Startups without established businesses have little to lose economically from such shakeups. Culturally, startups often pride themselves on being disruptive and changing the world; startup employees tend to view these shakeups optimistically. ${ }^{232}$ One prevalent cliché about startups, sometimes mocked in popular culture, is that they attract people who "want to make the world a better place."233 Startup entrepreneurs are "socialized to believe that most problems can be fixed with enough money and engineering."234 Furthermore, startup culture, particularly in Silicon Valley, has become known to foster a certain libertarian-leaning, free-market ideology that views technology that appeals to the masses as democratic. ${ }^{235}$ Given this confluence of factors, it is not surprising that startups might be inclined to "Move Fast and Break Things," as Facebook's motivational posters implored its employees to do. ${ }^{236}$

Established companies, almost by definition, have stable, profitable businesses. This gives them reason to worry about radical changes to the law that might undermine or even eliminate those businesses; no one wants to kill the golden goose in attempt to get more eggs. Moreover, a new and uncertain line of business will demand a large amount of managers' finite attention, which can detract from the company's already-developed business lines. Established companies might also be dissuaded from pivoting their business models to ones

${ }^{232}$ Indeed, the term "disruptive" has become so overused in Silicon Valley that some companies have started consciously avoiding it. See Max Nisen, How 'Disrupt' Got Turned Into An Overused Buzzword, BUS. INSIDER (Sept. 28, 2013), http://www.businessinsider.com/how-siliconvalley-killed-disruption-2013-9; Emily Inverso, The Most Obnoxious and Overused Startup Jargon, FORBES (Mar. 16, 2015), http://www.forbes.com/sites/emilyinverso/2015/03/16/the-mostobnoxious-and-overused-startup-jargon/\#785d552740c9.

${ }^{233}$ See, e.g., Adam Levene, Beyond Disruption: The Age of the Impact Entrepreneur, WIRED (Oct. 2014), http://www.wired.com/insights/2014/10/the-age-of-the-impact-entrepreneur/; Sam Biddle, TechCrunch Speaker Combines Every Possible Startup Cliché, ValleyWag (May 6, 2014), http://valleywag.gawker.com/change-the-world-power-influence-innovation-hand-g-1573559085.

${ }^{234}$ Brian Fung, The Real World Is Undermining Silicon Valley's Apolitical Fantasyland, WASH. Post (Aug. 20, 2014), https://www.washingtonpost.com/news/the-switch/wp/2014/08/20/the-realworld-is-undermining-silicon-valleys-apolitical-fantasyland/.

${ }^{235}$ Paul Carr, Travis Shrugged: The Creepy, Dangerous Ideology Behind Silicon Valley's Cult of Disruption, PANDO (Oct. 24, 2012), https://pando.com/2012/10/24/travis-shrugged/ ("To proponents of Disruption, the free market is king, and regulation is always the enemy."); Fung, supra note 234 ("A belief in permissionless innovation is what gives the tech industry its libertarian streak.”); Gregory Ferenstein, Silicon Valley Represents An Entirely New Political Category, TeChCRUNCH (Nov. 8, 2015), http://techcrunch.com/2015/11/08/silicon-valleyrepresents-an-entirely-new-political-category/ (noting that author conducted a political psychology study of the tech industry and "[t]he results suggest that Internet startup founders represent an entirely distinct, libertarian-like ideology within the Democratic party. Tech startup founders see the government as an investor in citizens, rather than as a protector from capitalism.").

${ }^{236}$ Ashlee Vance, Facebook: The Making of 1 Billion Users, BLOOMBERG BusINESS (Oct. 4, 2012), http://www.bloomberg.com/bw/articles/2012-10-04/facebook-the-making-of-1-billionusers. 
that require regulatory entrepreneurship because they fear the bad press that might come from being seen as operating in a legal gray area or breaking the law. More generally, established businesses and customer relations require a certain degree of stability and predictability. They tend to be larger and thus have more levels of internal hierarchy. Their employees tend to be older than startup employees, and they tend to attract employees who prefer the more stable prospects that come from working at an established business to high-risk, high-reward startup employment.

Despite these obstacles, established companies are capable of engaging in regulatory entrepreneurship as well. Google is perhaps the best example. Its founders have remained committed to taking on big and complex problems and applying creative solutions, and warned prospective IPO investors that Google would continue to take on moonshot projects after it went public. ${ }^{237}$ One of the company's most important moonshot investments is the self-driving car project. ${ }^{238}$ This project always had at its heart the obstacle that it would have to change the law to be viable. To date, Google is a leader in self-driving car technology, and has persuaded California, Florida, Michigan, Nevada, and Washington D.C. to pass laws that allow public road testing. ${ }^{239}$

Yet Google is, in some ways, the exception that proves the rule. Though now a well-established company, it began as a startup that experienced tremendous success, and its startup culture persists, at least in part. Further, Google's founders put in place a dual-class stock structure which guaranteed that they would retain control of the company and could not be forced to change course by dissatisfied outside investors. ${ }^{240}$ This structure, combined with the perception that they are visionary tech leaders and the deference that the market is willing to accord them as a result, gives Google significant freedom to engage in regulatory entrepreneurship, as well as take on other types of risky projects.

\footnotetext{
${ }^{237}$ Alphabet Investor Relations, 2004 Founders' IPO Letter From the S-1 Registration Statement, "An Owner's Manual" for Google's Shareholders, available at https://abc.xyz/investor/foundersletters/2004/ipo-letter.html ("We will not shy away from high-risk, high-reward projects because of short term earnings pressure. . . Do not be surprised if we place smaller bets in areas that seem very speculative or even very strange when compared to our current businesses.").

${ }^{238}$ Steven Levy, Google's Larry Page on Why Moon Shots Matter, WIRED (Jan. 17, 2013, 6:30 AM), http://www.wired.com/2013/01/ff-qa-larry-page/.

${ }^{239}$ Alex Knapp, Nevada Passes Law Authorizing Driverless Cars, Forbes (June 22, 2011); Dino Grandoni, Among the States, Self-Driving Cars Have Ignited a Gold Rush, N.Y. TIMES (Aug. 6, 2015), http://www.nytimes.com/2015/08/07/automobiles/self-driving-cars-ignite-gold-rushamong-states.html.

${ }^{240}$ Edward B. Rock, Shareholder Eugenics in the Public Corporation, 97 CORNELL L. REV. 849, 900 (2012); Steven Davidoff Solomon, New Share Class Gives Google Founders Tighter Control, N.Y. TiMES DEALBOOK (Apr. 13, 2012, 9:17 AM), http://dealbook.nytimes.com/2012/04/13/newshare-class-gives-google-founders-tighter-control/; Steven Davidoff Solomon, Thorny Side Effects in Silicon Valley Tactic to Keep Control, N.Y. Times DealbooK (Sept. 3, 2013, 5:16 PM), http://dealbook.nytimes.com/2013/09/03/thorny-side-effects-in-silicon-valley-tactic-to-keepcontrol/.
} 
Even so, investors became increasingly uneasy about both the amount and opacity of Google's spending on far-out technology projects that were unrelated to its core business of advertising and search. ${ }^{241}$ Ultimately, Google responded to mounting investor pressure by embarking on a major reorganization of its business. According to one former Google executive: "It was getting harder and harder to hide the costs of some of the company's projects," especially as some of these speculative ventures were bound to fail, and "It's easier to take the core business and run it like a Fortune 500 company."242

Google, Inc. recently restructured to a holding company, Alphabet, Inc., with a host of subsidiaries. ${ }^{243}$ Under the new structure, Alphabet has partitioned off the moonshot technology projects into a separate subsidiary, X, framed as Alphabet's incubator. ${ }^{244}$ The projects that turn into viable businesses will be spun off or "graduated" as their own standalone companies. ${ }^{245}$ Google's self-driving car project is expected to "graduate" into its own company soon. ${ }^{246}$

\section{The FUture OF REgULATORY ENTREPRENEURSHIP}

We now consider whether regulatory entrepreneurship is likely to be a temporary phenomenon, or one that we will continue to see more of in the future. We then examine how we believe that regulatory entrepreneurship will shape our laws in the years to come.

\section{A. The Prospects for Regulatory Entrepreneurship Going Forward}

Part II identified and examined the primary factors that make regulatory entrepreneurship a promising or dubious strategy. By considering how those factors will weigh out in the future, we can gain insight into the likely prevalence of regulatory entrepreneurship going forward.

Anticipating the law-related factors necessarily means making some predictions about the course of politics and future policy making, which is a difficult prospect at best. We simply note that the national government is currently divided and gridlocked due to increased political polarization, and that this state of affairs may continue for some time. ${ }^{247}$ If so, relative inaction by the

${ }^{241}$ See Alistair Barr \& Rolfe Winkler, Google Creates Parent Company Called Alphabet in Restructuring, WALL ST. J. (Aug. 10, 2015), http://www.wsj.com/articles/google-creates-newcompany-alphabet-1439240645.

${ }^{242}$ Id.

243 Google, Google Announces Plans for New Operating Structure, Aug. 10, 2015, https://investor.google.com/releases/2015/0810.html.

${ }^{244}$ Mark Bergen, Google X Has a New Logo and New Plan to Turn Moonshots Into Actual Businesses, RECODE (Jan. 13, 2016), http://recode.net/2016/01/13/google-x-has-a-new-logo-andnew-plan-to-turn-moonshots-into-actual-businesses/.

${ }^{245}$ See Barr \& Winkler, supra note 241.

${ }^{246}$ Bergen, supra note 244.

${ }^{247}$ See Pew Research Center, Political Polarization in the American Public (June 12, 2014), http://www.people-press.org/2014/06/12/political-polarization-in-the-american-public/ (discussing 
national government in many spheres will leave more issues for state and local governments to address, and more room for those governments to maneuver. ${ }^{248}$ This could produce a more favorable legal landscape for regulatory entrepreneurship. $^{249}$

Similarly, future prospects for regulatory entrepreneurship will depend on the health of the ecosystem that supports and promotes startups. A mature industry has arisen around providing startups with capital; this has come with infrastructure - such as people with experience evaluating startup investment opportunities - that is likely to prove durable. ${ }^{250}$ Venture capital is a crucial part of the ecosystem, but it includes other participants as well such as angel investors, accelerators, and incubators. ${ }^{251}$ In addition, recent legal changes have opened up new avenues for investment in startups. ${ }^{252}$ Also importantly, investors have become increasingly comfortable with regulatory entrepreneurship as a business strategy, and the infrastructure that has been assembled to date will facilitate this on an ongoing basis.

But perhaps the most important factors for the future of regulatory entrepreneurship are business-related. As noted previously, the growth of platform companies has been a significant driver of increased regulatory entrepreneurship. One might therefore expect that the prospects for regulatory entrepreneurship are tied, at least in part, to the fate of new platform companies.

There are some reasons to think that new platform companies will have issues achieving large, connected user bases and significant amounts of capital. Both of these are important for regulatory entrepreneurship: Skillful use of a large, connected user base has become arguably the most effective weapon in the modern regulatory entrepreneur's arsenal. Money is also important-companies that can credibly threaten to commit lots of resources to political battles, and to be

upward trend in political polarization); Pew Research Center, Partisan Polarization Surges in Bush, Obama Years (June 4, 2012), http://www.people-press.org/2012/06/04/partisanpolarization-surges-in-bush-obama-years/ (same); Unprecedently Dysfunctional, THE ECONOMIST

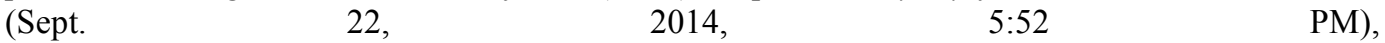
http://www.economist.com/blogs/democracyinamerica/2014/09/political-gridlock.

${ }^{248}$ Moreover, at the federal level, congressional gridlock makes it more likely that Presidents will seek to accomplish their political goals through administrative agencies and other executive actions. To the extent that it is easier (harder) for companies to influence executive action, this will further promote (discourage) regulatory entrepreneurship.

249 See supra Part III.B.

${ }^{250}$ See Nat'1 Venture Capital Ass'n, \$58.8 Billion in Venture Capital Invested Across U.S. in 2015, According to the MoneyTree Report, Jan. 15, 2016, http://nvca.org/pressreleases/58-8-billion-inventure-capital-invested-across-u-s-in-2015-according-to-the-moneytree-report-2/; Darian $\mathrm{M}$. Ibrahim, Financing the Next Silicon Valley, 87 WASH. U. L. REV. 717 (2010).

251 Brad Bernthal, Investment Accelerators, STANFORD J.L. BUS. \& FIN. (forthcoming 2016); Ibrahim, Angel Investors, supra note250; Dana Thompson, Accelerating the Growth of the Next Generation of Innovators, 8 OHIO ST. ENTREPRENEURIAL BUS. L.J. 279 (2013).

${ }^{252}$ See U.S. Securities and Exchange Comm'n, SEC Adopts Rules to Permit Crowdfunding, Oct. 30, 2015, https://www.sec.gov/news/pressrelease/2015-249.html; Darian M. Ibrahim, Equity Crowdfunding: A Market for Lemons?, 100 MINN. L. REV. 561 (2015). 
able to stay in the game for the long haul, are more likely to succeed than those that cannot. ${ }^{253}$

One issue that platform companies face is that they are, by their nature, middlemen who profit from facilitating transactions between other parties. Consequently, the parties the platform connects have an incentive to try and cut the platform company out of the transaction. ${ }^{254}$ In many instances, this may be achievable. ${ }^{255}$ Circumvention is generally a manageable problem for Airbnb and Uber because of the nature of their underlying businesses. Travelers usually go to different places over time, so they cannot simply reuse the same Airbnb host over and over. Uber passengers usually want to find the driver closest to their location at the moment they need a ride. This is not easy to do without their app. There are other platform companies whose business models provide similar safeguards against being easily circumvented. ${ }^{256}$ But, for many platform companies, this is a major issue that can greatly undermine the user base and financial resources that the company needs to be politically effective. ${ }^{257}$ Furthermore, even if a new platform company did not suffer from circumvention issues, regulatory entrepreneurship will only be appealing if there is a potentially changeable law that materially affects the value of the business. Combined, this would seem to

${ }^{253}$ See, e.g., DRUTMAN, supra note 10, at 238; Helderman, supra note 104.

${ }^{254} \mathrm{Cf}$. Jordan Barry et al., Voluntary Transaction Costs (giving a similar example in more detail).

${ }^{255}$ For example, imagine a platform that connects people who need haircuts to stylists, similar to Glamsquad or StyleBee. The stylist and customer, once they have been introduced, can easily contact each other to conduct future business without going through the platform.

${ }^{256}$ For example, Cherry allowed people to park anywhere, then call in someone nearby to clean their car. The importance of the car washer's proximity, much like that of an Uber driver, made it more difficult to circumvent the company's app. However, the company-which likely would have needed to change zoning laws in many cities for its business to successfully scale up in the long run-went out of business because of low transaction volume. See Semil Shah, Iterations:

Lessons We Can Draw from Cherry, TECHCRUNCH (Jan. 13, 2013), http://techcrunch.com/2013/01/13/iterations-lessons-we-can-draw-from-cherry/; 11 Uber for $X$ Startups That Failed-Are You Making the Same Mistakes?, NeXTJuggernaut (Apr. 28, 2015), $\mathrm{http}: / /$ nextjuggernaut.com/blog/11-uber-for-x-startups-that-failed-are-you-making-the-samemistakes/.

Alternatively, a platform company could bring together customers with providers of more specialized services that users do not typically need to re-hire regularly, such as personal injury lawyers or windshield installers. $C f$. Handy (lets users bring in plumbers, electricians, etc. to their homes) and Thumbtack (hire all sorts of random services). However, the non-repeat nature of transactions would seem to limit users' connectivity with the company and the company's valuation. But see Ingrid Lunden, Handy Raises \$50M Led By Fidelity, Reportedly At \$500M Valuation, To Clean Up In Home Services, TECHCRUNCH (Nov. 2, 2015), http://techcrunch.com/2015/11/02/handy-50m-fidelity/\#.9x7xuja:jLS2; Rolfe Winkler \& Telis Demos, Investors Strike Back on Silicon Valley Valuations, Wall ST. J. (Oct. 20, 2015), http://blogs.wsj.com/digits/2015/10/20/investors-strike-back-on-silicon-valley-valuations/

(describing how Thumbtack secured new funding at a $\$ 1.3$ billion valuation, which, while less than the $\$ 2$ billion-plus valuation it had been seeking, is considerable).

${ }^{257}$ See, e.g., Zeel (provides massage therapists); Your-Mechanic (sends mechanics); TutorSpree (connected people with tutors, but was shut down); Urban-sitter (sends babysitters); Washio (laundry pick-up and delivery); DogVacay (pet-sitting services); Instacart (grocery shopping services); BloomThat (flower delivery); Pager (doctors); Glamsquad (hair and makeup stylists); Eaze (medical marijuana delivery). 
suggest that only a narrow range of businesses stand to gain from a regulatory entrepreneurship strategy.

However, we believe that there is an even stronger argument that the business fundamentals favor increased regulatory entrepreneurship in the years to come. This argument is sometimes referred to as the "back half of the chessboard" argument. ${ }^{258}$ The name of this argument comes from a legend that the inventor of chess was brought before the king, who offered him a reward. The inventor asked for a grain of rice to be placed on the first square of a chessboard; then two grains on the second square the next day; four grains on the third square the day after; eight grains on the fourth square the day after that, and so on, doubling the previous day's total each day until the sixty-fourth day. The king agreed. Only later did he realize that he had promised the inventor more rice than has been produced in the history of the world, and that the agreement has bankrupted his kingdom. ${ }^{259}$

Like the grains of rice on the chessboard, technological progress tends to exhibit exponential growth. ${ }^{260}$ This has been particularly true of the computer industry; for the last fifty years, computer technology has doubled in power approximately every two years. ${ }^{261}$ This is sometimes referred to as Moore's law, after the author of the paper that first predicted this pattern. ${ }^{262}$ When Moore first wrote his paper, the degree to which computers would increase in computational power, while becoming smaller and more affordable, was almost impossible to appreciate. $^{263}$ Even with the benefit of hindsight, it is difficult to wrap one's head around this meteoric growth; many individuals now carry more computing power in their pockets than NASA possessed at the time of the moon landing. ${ }^{264}$ And,

\footnotetext{
${ }^{258}$ See ERIK Brynjolfsson \& ANDrew McAfee, The Second Machine Age: Work, Progress, AND PROSPERITy IN A TIME of BRILliant TEChNOlogies (2014); ERIK BRYNJOlFSSON \& Andrew McAfee, Race Against the Machine: How the Digital Revolution Is ACCELERATING INNOVATION, DRIVING PRODUCTIVITY, AND IRREVERSIBly TRANSFORMING EMPLOYMENT AND THE ECONOMY (2001).

${ }^{259}$ Accounts differ as to whether, upon this discovery, the king rewards the inventor for his cleverness by making him a high-ranking advisor, or executes him for tricking the king. See Malba Tahan, The Man Who Counted: A Collection of Mathematical AdVEnTures 11315 (1993); SECOND MACHINE AGE, supra note 258, at 45-47.

${ }^{260}$ This is because technological gains feed into each other, so that today's gains lead to greater gains in the future.

${ }^{261}$ More precisely, the number of transistors in a dense integrated circuit doubles approximately every two years.

${ }^{262}$ See Gordon E. Moore, Cramming More Components Onto Integrated Circuits, ElECTRONICS MAGAZINE at 4 (1965). Gordon E. Moore is the founder of Intel.

${ }^{263}$ See, e.g., Nick Carr, How Many Computers Does the World Need? Fewer Than You Think, GUARDIAN (Feb. 20, 2008), http://www.theguardian.com/technology/2008/feb/21/computing.supercomputers ("In the early 1940s, IBM's President, Thomas J. Watson, reputedly said: 'I think there is a world market for about five computers."').

${ }^{264}$ See, e.g., A Modern Smartphone or a Vintage Supercomputer: Which Is More Powerful?, PhONEARENA (June 14, 2014), http://www.phonearena.com/news/A-modern-smartphone-or-avintage-supercomputer-which-is-more-powerful_id57149 (quoting physicist Michio Kaku).
} 
assuming that Moore's law continues to hold, ${ }^{265}$ the next few years will add more computing power than the past fifty years, combined-and then the next few years will add much more still.

It is hard to predict exactly how all of this additional computing power will be used. ${ }^{266}$ However, it seems a safe bet that we will be increasingly connected and accessible - which will give companies new ways to mobilize large groups of people on their behalf. Companies are also likely to have more data about their users, and greater ability to organize and analyze this information. This will make companies better able to channel and leverage their users for maximum effect. All of this suggests that regulatory entrepreneurship will be an increasingly attractive proposition and that we will therefore see more of it, even if we cannot quite anticipate the exact form that it is likely to take.

\section{B. How Regulatory Entrepreneurship Will Affect Legislation}

Because regulatory entrepreneurship may become an increasingly common phenomenon, we believe that its effects on lawmaking merit careful consideration. We begin with a discussion of scholarly accounts of the political process and how they relate to regulatory entrepreneurship generally. We then turn to some well-known political pathologies and consider the extent to which regulatory entrepreneurship might ameliorate them. Finally, we consider the limits of regulatory entrepreneurship's potential to improve political outcomes and assess its likely effects overall.

\section{The Political Process}

The democratic political process involves a messy, complicated interplay of different groups of people pursuing varied goals. Political scientists and economists have proposed a number of frameworks for understanding this process and its outputs.

One of the most famous and most popular has come to be known as the "Bootleggers and Baptists" framework. ${ }^{267}$ This name comes from the observation

\footnotetext{
${ }^{265}$ There have been many predictions that Moore's Law will fail over the last fifty years. To date, they have all proved wrong. For example, Gordon Moore himself predicted in 1995 that Moore's Law wouldn't hold after 2005. He then updated his prediction in 2005, predicting that it would last until between 2015 and 2025. In 2015, he updated once again, saying that it would end in 2025. See The End of Moore's Law, THE Economist, Apr. 19, 2015, http://www.economist.com/blogs/economist-explains/2015/04/economist-explains-17 (collecting these and other examples).

${ }^{266}$ See, e.g., Daniel Burrus, The Internet of Things Is Far Bigger Than Anyone Realizes, WIRED Nov. 2014), http://www.wired.com/insights/2014/11/the-internet-of-things-bigger/.

${ }^{267}$ See, e.g., Bruce L. Benson et al., Implicit Taxes Collected by State Liquor Monopolies, 115 Public Choice 313 (2003); Erika Meins, Politics and Public Outrage: Explaining TRANSATLANTIC AND INTRA-EUROPEAN DIVERSITY OF REGULATIONS ON FOOD IRRADIATION AND GenetiCally Modified FoOd (2003); Alan Reynolds, The Politics of NAFTA, 45 NAT'L Rev. 20, 42-43 (1993); Alan E. Wiseman \& Jerry Ellig, The Politics of Wine: Trade Barriers, Interest
} 
that both bootleggers and Baptists supported laws restricting liquor sales. The latter supported these laws because they opposed the consumption of alcohol. The former clearly had no such compunction; instead, they wished to profit by restricting competition from legal sales of alcohol. Although these seemingly opposed groups had very different preferences and aims, both supported regulations on liquor sales and were instrumental in their enactment. The Baptists fulfill important public roles, including presenting a sympathetic face on the legislation, building popular support, and providing "moral cover."268 The bootleggers work behind the scenes, contributing resources and "lubricat[ing] the political machinery." 269

The bootleggers and Baptists model produces several important insights, but for our purposes two are paramount. First, when pursuing one's self interest - that is, when one is a bootlegger, seeking a policy change for profitshaving a good altruistic cover (that is, Baptists) is very helpful.

The most successful modern regulatory entrepreneurs have proved adroit at finding sympathetic groups to serve as the public faces for their issues. They are, in a sense, bootleggers who create their own Baptists. For example, consider how Uber fights political battles with taxi regulators and local governments. As much as possible, Uber makes the public face of the issue its drivers, who stand to lose their livelihoods, and its riders, who face unmet transportation needs. ${ }^{270}$ Similarly, Airbnb uses hosts who need to rent out spare rooms in order to make ends meet; ${ }^{271}$ Airbnb's opponents have worked hard to put less appealing faces on the issue. ${ }^{272}$

Companies who do not have ready-made, photogenic Baptists have had more difficulty achieving their political goals. For example, consider Tesla Motors' options for garnering mass public support. Until recently, its cheapest car had a $\$ 70,000$ price tag, which is well out of most people's price range, and its dealerships do not hire large numbers of low-income workers. ${ }^{273}$ Tesla has made other arguments to support its regulatory aims, but they have not always resonated

Groups, and the Commerce Class, 69 J. Politics 859 (2007); BRUCE YANDle, BootlegGers, BAPTISTS AND GlOBAL WARMING (1999); Bruce Yandle, Bootleggers and Baptists in Retrospect, 22 Regulation 3 (2007); Bruce Yandle, Bootlegger and Baptists: The Education of a Regulatory Economist, REgUlation 12, 12-16 (May-June 1983).

${ }^{268}$ Randy T. Simmons et al., Bootleggers, Baptists, and Political Entrepreneurs: Key Players in the Rational Game and Morality Play of Regulatory Politics, 15 INDEPENDENT REV. 367 (2011); Yandle, Bootleggers and Baptists in Retrospect, supra note Error! Bookmark not defined..

${ }^{269}$ Simmons et al., supra note 268 , at 368.

${ }^{270}$ Uber, supra note 162.

${ }^{271}$ See supra notes 152-155 and accompanying text.

${ }^{272}$ See supra notes 156-161 and accompanying text.

273 See, e.g., Farhad Manjoo, The Genius of Tesla, Slate, May 10, 2013,

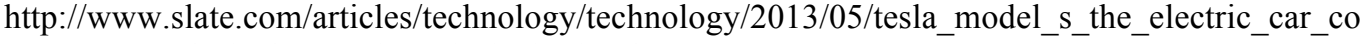
mpany_is_a_little_bit_apple_a_little_bit.html. 
with the public. ${ }^{274}$ DraftKings and FanDuel have tried to make their users their public face of their fight, lamenting that state governments are preventing their users from playing games that they enjoy, ${ }^{275}$ but may have difficulty selling this argument. $^{276}$ Google's self-driving cars are haunted by public concern that driverless cars will eliminate thousands of existing jobs. ${ }^{277}$

The second important insight is that changing the law often requires action by multiple interest groups with divergent goals. This raises the question of how these groups coordinate their efforts; as one scholar put it, "It seems unlikely that the local Baptist preacher and the moonshiners meet in someone's parlor to discuss banning Sunday [liquor] sales." ${ }^{, 78}$ Someone or something else must act as intermediaries and coalition-builders, knitting together support from disparate groups in order to accomplish legal change. ${ }^{279}$

${ }^{274}$ Tesla has made arguments based on the beneficial impact its cars will have on the environment, particularly with respect to carbon emissions, and by appealing to the principle of consumer freedom. See, e.g., Musk, supra note 59. The former argument seems undermined by the significant percentage of people who do not believe in climate change and the latter by the fact that the consumers in question have high incomes and other good car-buying options, perhaps making them less sympathetic to many voters.

${ }^{275}$ Kulwin \& Wagner, supra note 106.

276 This is a tricky maneuver. Casual players might not care about this, and thus are not necessarily likely to offer huge waves of public support. Looking at the heavy users is also somewhat problematic; the vast majority of winnings on these sites go to a small group of sophisticated players who enter hundreds of contests a day and use advanced mathematical techniques to maximize their profits. See, e.g., Joshua Brustein \& Ira Boudway, You Aren't Good Enough to Win Money Playing Daily Fantasy Football, Bloomberg (Sept. 10, 2015), http://www.bloomberg.com/news/articles/2015-09-10/you-aren-t-good-enough-to-win-moneyplaying-daily-fantasy-football; Drew Harwell, All the Reasons You (Probably) Won't Win Money Playing Daily Fantasy Sports, WASHINGTON POST, Oct. 12, 2015, https://www.washingtonpost.com/news/the-switch/wp/2015/10/12/all-the-reasons-you-probablywont-win-money-playing-daily-fantasy-sports/. DraftKings and FanDuel must also contend with historic (though waning) unfavorable views of gambling and the fact that they are often fighting battles in courts instead of the political arena.

${ }^{277}$ See, e.g., Martin Ford, The Rise of Automated Cars Will Kill Thousands of Jobs Beyond Driving, GIZMODO, May 7, 2015, http://gizmodo.com/the-rise-of-automated-cars-will-thousandsof-jobs-and-n-1702689348; Chunka Mui, Will Driverless Cars Force A Choice Between Lives And Jobs?, FORBES, Dec. 19, 2013, http://www.forbes.com/sites/chunkamui/2013/12/19/will-thegoogle-car-force-a-choice-between-lives-and-jobs/\#1f12eea9546e; Zack Kanter, How Uber's Autonomous Cars Will Destroy 10 Million Jobs And Reshape The Economy by 2025, CBS LOCAL, Jan. 27, 2015, http://sanfrancisco.cbslocal.com/2015/01/27/how-ubers-autonomous-cars-willdestroy-10-million-jobs-and-reshape-the-economy-by-2025-lyft-google-zack-kanter/; Sam Tracy, Autonomous Vehicles Will Replace Taxi Drivers, But That's Just the Beginning, Huffington Post, June 12, 2015, http://www.huffingtonpost.com/sam-tracy/autonomous-vehicles-willb_7556660.html.

${ }^{278}{ }^{-}$Simmons et al., supra note 268, at 368 .

${ }^{279}$ Sociologists Neil Fligstein and Douglas McAdam have recently theorized the nature of social change, from political movements to market meltdowns, and have included the idea of "internal governance units" which they define as organizations or associations who play a connecting role with state actors and who provide information to actors within a "strategic action field." NEIL FLigsteIn \& Douglas McAdAM, A THEORY OF Fields 77 (2012). 
The dominant view is that, historically, politicians, and occasionally highranking bureaucrats, have taken on this role. ${ }^{280}$ Such politicians are sometimes described as "political entrepreneurs." 281

Regulatory entrepreneurs have some similarities to political entrepreneurs, but they differ in several key ways. First, political entrepreneurs usually take advantage of pre-existing, organized interest groups. ${ }^{282}$ Modern regulatory entrepreneurs, in contrast, have largely identified unorganized groups and mobilized them. ${ }^{283}$ "People for Deregulated Taxicabs," "People for Short-Term Rentals," and "Citizens Against Car Dealerships" were not established political groups that adopted the cause of Uber, Airbnb, and Tesla; instead, these companies organized people who were sympathetic to these positions and mobilized them to take action.

Second, political entrepreneurs have usually had one of two primary (compatible) motivations: a values-based preference, rooted in ideology or otherwise, for a particular policy, or advancing their political careers. Regulatory entrepreneurs, in contrast, are primarily motivated by the desire to earn profits.

Third, while political entrepreneurs are individuals, usually elected officials, regulatory entrepreneurs are primarily privately owned businesses. One key implication of this pertains to how policies spread across jurisdictions. Because of the structure of the U.S. political system, politicians usually have bases of support centered on particular geographic areas. A mayor is well equipped to influence policy in her city, but her network strength is unlikely to reach other jurisdictions. It is true that successful mayors often parlay that success into election to statewide office, and that successful state politicians often parlay that success into national political office. ${ }^{284}$ However, the positions available at higher levels of government are structurally limited - the number of governors, members of Congress, and Presidents are fixed-which constrains the amount of movement that can occur up the chain, especially when incumbents' well-documented electoral advantages are taken into account. ${ }^{285}$ Moreover, in our federalist system, different levels of government have dominion over different questions. Thus, many issues that a mayor might build a coalition around do not translate to state politics; the same issue applies for state politicians moving to the

\footnotetext{
${ }^{280}$ Simmons et al., supra note 268 , at 368 .

281 See, e.g., id.; see also LEADERShIP AND INNOVATION: A BIOGRAPHIC PERSPECTIVE ON ENTREPRENEURS IN GOVERNMENT (Jameson Doig \& Erwin C. Hargrove eds., 1987). The term is also sometimes used to refer to businesses who pursue a rent-seeking strategy. See, e.g., Matthew McCaffrey \& Joseph T. Salerno, A Theory of Political Entrepreneurship, 2 MODERN ECONOMY 552 (2011).

${ }^{282}$ Simmons et al., supra note 268.

283 Justin Fox, Uber Is Lobbying for All of Us, BLOOMBERG VIEW (June 29, 2015).

${ }^{284}$ Martin O'Malley, for example, was elected Mayor of Baltimore, then Governor of Maryland, then unsuccessfully sought the Democratic Party nomination for President.

${ }^{285}$ See, e.g., Gary W. Cox \& Jonathan N. Katz, Why Did the Incumbency Advantage in U.S. House Elections Grow?, 40 AM. J. POL. SCI. 478 (1996).
} 
national political arena. Furthermore, politicians in the United States generally do not move among parallel levels of government; a successful mayor of San Diego is not likely to run for mayor of Los Angeles. Similarly, in modern U.S. political history, no candidate has ever been elected governor of two different states. ${ }^{286}$

Businesses, in contrast, are not constrained in the same ways. The number of businesses of a particular size or operating in a given industry is not intrinsically fixed. More importantly, businesses are focused on growing their customer bases geographically in a way that politicians generally are not. Thus, a business that succeeds in establishing a winning electoral coalition that works at the city level in San Diego is much more likely to try to repeat its success in Los Angeles, or from one state to another.

Taken together, these differences suggest that regulatory entrepreneurship will lead to different coalitions being formed, and therefore different laws being enacted, than has been the case historically. Regulatory entrepreneurship seems most likely to have the largest effect on policymaking at the local and state level, in the sphere of economic regulation, and to feature groups that are not currently as organized in American politics.

\section{The Problem of Asymmetric Benefit Concentration}

Every political process is imperfect, ${ }^{287}$ and ours is no exception. Scholars have documented a number of pathologies that can lead to inefficient outcomes. ${ }^{288}$ One common circumstance in which the political process can often produce suboptimal outcomes is when there are asymmetries between how a policy's costs and benefits are distributed.

For example, consider a policy that produces concentrated benefits but diffuse costs - that is, it provides significant benefits to a relatively small group of people, while imposing relatively small costs on each member of a large group of people. In such circumstances, the beneficiaries of the proposed policy have a lot of incentive to fight for that policy. On the other hand, each of those who would be hurt by the policy has little incentive to resist it, since she would suffer only a small loss if it were enacted. These asymmetric incentives can result in the policy

\footnotetext{
286 Bill Federer, Only Man Ever Elected Governor of 2 States, WND (Oct. 21, 2015), http://www.wnd.com/2015/10/only-man-ever-elected-governor-of-2-states/.

${ }^{287}$ See KenNeth J. ARrow, Social Choice and Individual Values (2d ed. 1970). According to Arrow's "impossibility" theorem, there are no procedures for collective or social ordering of alternative choices that satisfy reasonable assumptions concerning the autonomy of the people and the rationality of their preferences. As such, there is no perfect set of decision-making processes or institutions. William Roberts Clark et Al., Principles of Comparative Politics 11 (2d ed. 2012).

${ }^{288}$ See, e.g., Lester G. Telser, The Usefulness of Core Theory in Economics, 8 J. ECON. PERSP. 151 (Spring 1994); see also Jordan M Barry et al., On Derivatives Markets and Social Welfare: A Theory of Empty Voting and Hidden Ownership, 99 VA. L. REV. 1103 (2013).
} 
being enacted, even if the policy inflicts more aggregate harm to those hurt by it than it benefits the policy's proponents.

There are a number of policy areas that embody this dynamic. Many involve incumbent members of an industry using legal restrictions to exclude potential competitors. This reduced competition enables the incumbent firms to charge higher prices, which can significantly raise their profits. Moreover, the incumbent firms are often organized into a trade association and, in some instances, a handful of firms may account for a large portion of total market share. This gives them strong incentive to push for these policies, and makes collective action easier. At the same time, the increased costs are spread over a large group of customers as well as would-be competitors. This gives each of the policy's natural opponents little incentive to lobby against it and makes it difficult to organize and coordinate opponents' efforts.

\section{a. Occupational Licensing and Protectionism}

There are several ways in which incumbents can enact protectionist legislation, but one of the best-known examples is occupational licensingregulations that require individuals to obtain a government license or other official permission to pursue a particular vocation or profession. Occupational licensing requirements have expanded dramatically in the last sixty years; in 1950, fewer than 5\% of Americans worked in jobs that required licenses, versus roughly $10 \%$ in 1980 and more than $30 \%$ today. ${ }^{289}$ Clearly, occupational licensing can be useful; ${ }^{290}$ few people favor abandoning all licensing for surgeons or architects, for example. But licensing has spread far beyond the traditional professions, and many commentators have questioned the rationale for licensing occupations such as auctioneers, boxing timekeepers, and hair braiders. ${ }^{291}$ In many instances, securing these licenses can be extremely costly; for example, in some states, simply braiding hair for money requires years of classes and thousands of dollars in tuition. ${ }^{292}$

\footnotetext{
${ }^{289}$ Robert Litan, In Obama's Budget, an Effort to Rein in Occupational Licensing, WALL ST. J. (Feb. 9, 2015), http://blogs.wsj.com/washwire/2015/02/09/in-obamas-budget-an-effort-to-rein-inoccupational-licensing/; Jacob Goldstein, So You Think You Can Be a Hair Braider?, N.Y. TIMES MAG. (June 12, 2012), at MM20, available at http://www.nytimes.com/2012/06/17/magazine/soyou-think-you-can-be-a-hair-braider.html.

${ }^{290}$ Consumers may not be well equipped to evaluate the quality of certain specialized fields, and the cost of incompetence may be high.

${ }^{291}$ See, .e.g., Jacob Goldstein, So You Think You Can Be a Hair Braider?, N.Y. TIMES MAG. (June 12 2012), http://www.nytimes.com/2012/06/17/magazine/so-you-think-you-can-be-a-hairbraider.html.; Matthew Yglesias, Bill Callegari Trying to Trim Occupational Licensing in Texas, Slate (Dec. $\quad 7, \quad 2012, \quad 12: 27 \quad$ PM), http://www.slate.com/blogs/moneybox/2012/12/07/texas_occupational_licensing_state_rep_bill_c allegari_aims_to_deregulate.html.

${ }^{292}$ See, e.g., Goldstein, supra note 291 (discussing one would-be hair braider's experience in Utah, which requires "nearly two years of school and $\$ 16,000$ in tuition"); Institute for Justice, Braiding Freedom Project, http://braidingfreedom.com/ (discussing similar rules in Washington, Missouri, and Arkansas, among others).
} 
Overly protectionist occupational licensing has many problems. It makes it harder for workers to shift between industries, fueling unemployment. It makes products and services more expensive for customers and harder to obtain. It's been derided by politicians on both sides of the aisle, and the President recently proposed $\$ 15$ million to study its effects, to applause from both the left and the right. $^{293}$

Yet these rules have spread so much and proved so difficult to fight because of the political economy dynamics. ${ }^{294}$ Regulated groups fight vigorously to keep their protections, but most voters pay little attention to these issues; elections rarely turn on the rules that govern hair braiders, opticians, interior designers, or athletes' agents. ${ }^{295}$

As a result, this problem has been a difficult one to crack. But regulatory entrepreneurship has made some inroads where more traditional politics has not. Restrictive taxicab regulations endured for decades nationwide, but Uber has transformed the landscape in a short amount of time. For example, in the last seventy-five years, New York City increased its cab fleet from approximately $12,000 \mathrm{cab}$ medallions to $13,000 .^{296}$ In Uber's four years in New York City, it added almost 12,000 new for-hire cars to the city's streets. ${ }^{297}$ Uber has had significant effects on taxi regulations in many other cities as well. ${ }^{298}$

State laws requiring car manufacturers to sell through independent dealers are another form of entry restrictions or protectionism that have proved similarly durable, withstanding several efforts from the big car companies to repeal

\footnotetext{
${ }^{293}$ See Carrie Sheffield, How Cutting Red Tape Helps Low-Income Families, FORBES (Feb. 2, 2015, 8:43 PM), http://www.forbes.com/sites/carriesheffield/2015/02/02/can-cutting-red-tapegenerate-200b-for-low-income-families/\#379d12283523; Nick Timiraos, White House Warns States On Job-Licensing Requirements, WALL St. J. (July 30, 2015, 7:44 AM), $\mathrm{http} / / / \mathrm{blogs.wsj} . c o m /$ economics/2015/07/30/need-a-license-for-that-job-the-white-house-warnsstates-against-overdoing-it/; Litan, supra note 289.

${ }^{294}$ Timiraos, supra note 293.

${ }^{295}$ See Edward J. Timmons \& Anna Mills, Short-Sighted Policy, ECONOMIC InTELLIGENCE (Feb. 17, 2015); Matthew Yglesias, The Trouble with State Government, ThinK Progress (Feb. 28, 2009 , $5: 42$

PM), http:/thinkprogress.org/yglesias/2009/02/28/191948/the trouble_with_state_government/ (“[T]he lack of public attention paid to policymaking at the state, county, and municipal level leads to much more pure interest-group capture than you see on the federal level. Not that interest groups don't have a lot of clout in federal politics. But the relatively competitive nature of elections and the relatively bright spotlight shown on national politics puts a check on these things. At the state level, bad policy really runs amok.").

${ }^{296}$ Ginia Bellafante, Uber Makes Its Pain New Yorkers' Problem, N.Y. Times (July 24, 2015) .

${ }^{297} \mathrm{Id}$.

${ }^{298}$ See, e.g., Matthew Mitchell \& Michael Farren, A Common-Sense Solution to the Uber vs. Taxi Wars, L.A. Times (Nov. 19, 2015), http://www.latimes.com/opinion/op-ed/la-oe-1119-mitchellfarren-uber-taxis-deregulate-20151118-story.html (noting that some Florida counties have created a single set of regulations that apply equally to taxis and ride-share companies).
} 
them. $^{299}$ But in its decade of existence, Tesla motors has made real inroads against these laws, including convincing several states to pass new legislation that allows direct sales of automobiles to consumers. ${ }^{300}$

\section{b. Restrictive Zoning}

Restrictive zoning regulations provide a second example of how asymmetric distribution of costs and benefits can produce questionable policy. Most people in the United States currently live in apartments or houses that they own or rent for relatively long periods of time; in the past, a broader range of housing options were common. ${ }^{301}$ Many people were boarders, renting rooms in families' homes; others lived in rooming houses or residential hotels. ${ }^{302}$ Over time, zoning rules made these increasingly scarce. A major driver of this process was that these restrictions, by reducing the supply of housing, created concentrated benefits for local homeowners by raising the value of their homes, while the costs were spread more diffusely. Over time, the restricted supply of housing has contributed to a dramatic increase in housing prices. ${ }^{303}$

The restrictive zoning described above extends to other types of land use as well. Hosting a dinner party for your friends is legal, but if you were to serve the same dinner to paying customers, you would run afoul of regulations in many cities. ${ }^{304}$ Most cities require developments to set aside large amounts of space for

${ }^{299}$ Death of a Car Salesman, supra note 59; Crane, supra note 40, at 12.

${ }^{300}$ See, e.g., New Jersey Assembly Bill 3216, P.L. 2015 c.24; Eric D. Stolze, A Billion Dollar Franchise Fee? Tesla Motors' Battle for Direct Sales: State Dealer Franchise Law and Politics, 34 FRANCHISE L.J. 293, 305 (Winter 2015), available at http://www.americanbar.org/content/dam/aba/publications/franchising law journal/Winter 2015/ FLJ\%2034-3_01Stolze.authcheckdam.pdf; Todd Bishop, Tesla Wins Battle Against Auto Dealers in Washington State, But Future Rivals Are Screwed, GEEKWIRE (Feb. 18, 2014), http://www.geekwire.com/2014/tesla-wins-battle-auto-dealers-washington-state-future-rivalsscrewed/; Christopher DeMorro, Tesla Wins Big in North Carolina and New Hampshire, GAS2 (July 1, 2013), http://gas2.org/2013/07/01/tesla-wins-big-in-north-carolina-and-new-hampshire/; Brian Fung, Tesla Just Won a Huge Victory in New Jersey, Washington Post (Mar. 18, 2015), https://www.washingtonpost.com/news/the-switch/wp/2015/03/18/tesla-just-won-a-huge-victoryin-new-jersey/; Andrew Ganz, New Hampshire to Allow Tesla, Others to Sell Cars Direct to Consumers, LEFTLANENEws (June 26, 2013), http://www.leftlanenews.com/new-hampshire-toallow-tesla-others-to-sell-cars-direct-to-consumers.html.

301 Alan Durning, Unlocking Home: Three Keys to Affordable Communities (2013); PAul Groth, Living Downtown: The History of Residential Hotels in the United States (1999); Alan Durning, Bring Back Flophouses, Rooming Houses, and Microapartments, SLATE (July $17, \quad 2013, \quad 1: 27 \quad$ PM) http://www.slate.com/articles/business/moneybox/2013/07/sros_flophouses_microapartments_sma rt_cities_are_finally_allowing_the_right.html..

${ }^{30 \overline{2}} I d$.

${ }^{303}$ See, e.g., Edward Glaeser et al., Why Have Housing Prices Gone Up?, 95 AM. ECON. REV. 329 (2005).

${ }^{304}$ See Rachel Swan, Airbnb's New Dinner Sharing Venture “Completely Illegal” (Update), S.F. WEEKLY (June 4, 2014, 1:27 PM), http://www.sfweekly.com/thesnitch/2014/06/04/airbnbs-newdinner-sharing-venture-completely-illegal-update. 
parking. ${ }^{305}$ And so on. Taken together, these restrictions have had an enormous negative impact, producing massive demographic shifts, reducing economic growth, and damaging the environment. ${ }^{306}$

Regulatory entrepreneurship has the potential to partially ameliorate some of these problems. For example, it does not seem coincidental that one of Airbnb's toughest fights has been in San Francisco, a city with particularly restrictive zoning rules. ${ }^{307}$ San Francisco is located on a peninsula, so the only obvious way for the city to add housing units and business space is to grow vertically. $^{308}$ Yet most of San Francisco's neighborhoods restrict maximum building height to forty feet, and severely restrict how those buildings can be utilized. $^{309}$ At the same time, local homeowners have strong incentives to resist development, and they have done $\mathrm{so}^{310}$ - and the cost of residential and commercial real estate has soared. ${ }^{311}$ Airbnb, by enabling rental transactions that would otherwise not be possible, allows greater utilization of existing space and structures, effectively expanding the supply of real estate. ${ }^{312}$ Moreover, by allowing property owners and tenants to lease out unused residential space, Airbnb increases the range of uses to which property can be put. Similarly, Airbnb has launched a dinner sharing venture that allows users to host dinner parties for paying guests - effectively turning residential property into small restaurants. ${ }^{313}$ Airbnb is hardly unique in this respect; many other regulatory entrepreneurs' businesses undermine and reduce the impact of overly restrictive zoning regimes. ${ }^{314}$

\footnotetext{
${ }^{305}$ Donald Shoup, The High COST OF FreE PARKIng (2005).

${ }^{306}$ See, e.g., id.; David Schleicher, City Unplanning, 122 YALE L.J. 1670, 1674-75 (2013); Edward Glaeser et al., Urban Growth and Housing Supply, 6 J. ECON. GEO. 71 (2006); Timothy B. Lee, Zoning Laws Are Strangling Silicon Valley, ForBeS, (Sept. 19, 2011, 3:56 PM), http:/www.forbes.com/sites/timothylee/2011/09/19/zoning-laws-are-strangling-siliconvalley/\#3c49212d568b.

307 See, e.g., RyAn AvEnt, ThE GATED City (2011).

${ }^{308}$ Kyle Russell, This One Intersection Explains Why Housing Is So Expensive in San Francisco, BUSINESS INSIDER (Apr. 8, 2014), http://www.businessinsider.com/why-housing-is-so-expensivein-san-francisco-2014-4.

${ }^{309} \mathrm{Id}$.

${ }^{310}$ Kim Mai-Cutler, How Burrowing Owls Lead To Vomiting Anarchists (Or SF's Housing Crisis Explained), TECHCRUNCH (Apr. 14, 2014), http://techcrunch.com/2014/04/14/sf-housing/.

${ }^{311}$ Anna Marie Erwert, San Francisco’s Median Rent Hits a Ridiculous \$4,225, SF GATE (June 2, 2015), http://blog.sfgate.com/ontheblock/2015/06/02/san-franciscos-median-rent-hits-a-ridiculous4225/; Riley McDermid, Soaring S.F. Rents Restrict Tech Companies Ability to Expand, BIZ JOURNALS (Jan. 20, 2016), http://www.bizjournals.com/sanfrancisco/blog/realestate/2016/01/tech-office-rent.html.

${ }^{312}$ Lobel, supra note 168.

${ }^{313}$ Swan, supra note 304.

${ }^{314}$ Examples abound. A number of other companies, including Eat With, SupperKing, Feastly, and LeftOverSwap have taken similar tacks to Airbnb's dinner sharing business. Id. Cherry sought to turn every parking spot in San Francisco into a de facto car wash. See note 256, supra. HonkMobile, Parking Panda, Rover Park, WhereiPark, and other startups are turning residential driveways into commercial parking lots. Vanessa Lu, Parking Apps Will Allow Owners to Rent Out Parking Spots by the Hour, TORONTO STAR (May 21, 2015),
} 


\section{The Limits of Regulatory Entrepreneurship}

While regulatory entrepreneurship can ameliorate some of the political economy problems described above, it is no panacea. The limits and potential downsides of regulatory entrepreneurship are considerable.

First, regulatory entrepreneurs' ability to change the law will vary significantly depending on the nature of the business and the law in question; this creates real limits on regulatory entrepreneurs' ability to effect legal change. As noted above, platform companies are particularly well-suited for regulatory entrepreneurship, but the platform model is not always a good fit for a particular business. Moreover, some policy problems are not well-suited to a business of any type; a successful business based around fundamental tax reform seems unlikely, for example.

Even when regulatory entrepreneurship is a viable business strategy, regulatory entrepreneurs are not saints or altruists; they are profit-seeking actors, and they will generally use their political power to further their profit-seeking goals. Simply put, regulatory entrepreneurs do not want to get the socially optimal result, they want the result that is best for them. This can lead to suboptimal outcomes in a variety of ways.

To start, it is possible that the regulatory entrepreneur may push social policy away from the optimal outcome. The most direct way this can happen is when the regulatory entrepreneur's business is built on reversing an efficient regulatory regime. ${ }^{315}$ It is plausible that a regulatory entrepreneur who succeeds in building enough popular support to change the law is likely increasing general welfare, but this will not always be true. Popular support is a good indicator that a change in the law is a positive one, but there are several circumstances in which popular support may give little confidence that a legal change is efficient.

One such scenario is when a law's chief purpose is to address an externality that falls outside the jurisdiction. For instance, suppose Acmeville is considering relaxing its restrictions on water pollution, and that the main body of water affected is a river that flows through many other cities. Assuming that the proposed change is inefficient, a company based in Acmeville might still be able to gather substantial local support for it, because the Acmeville voters do not reap many of the benefits that the current law provides.

http://www.thestar.com/business/2015/05/21/parking-apps-will-allow-owners-to-rent-out-parkingspots-by-the-hour.html.

${ }^{315}$ For example, assume that cities' existing taxicab rules were efficient. Uber, by pushing to change those rules, would be moving society away from the optimal outcome. This is potentially consistent with Uber having popular support for its efforts: The efficient regime could involve small losses for many that are dwarfed by corresponding gains for others. Uber may merely have succeeded in organizing the former. 
A second circumstance in which popular support may be entitled to less weight is when there is a strong paternalism argument. This can arise when there is a reason to believe people will fail to adequately look out for their own interests, such as laws restricting gambling out of concern for the social costs of gambling addictions and the impact on disadvantaged or vulnerable populations. ${ }^{316}$ It can also arise when people have poor information that prevents them from understanding what they are getting or giving up by taking a certain action. $^{317}$

Regulatory entrepreneurship can also produce inefficiency in smaller ways; the regulatory entrepreneur may use its power to improve one policy outcome while worsening others. For example, many economists look favorably on Uber's efforts to increase competition in the taxi industry and to make prices more flexible. ${ }^{318}$ At the same time, Uber has often pushed for lower levels of required insurance coverage and less rigorous background checks than regulators favored. ${ }^{319}$ It is plausible that Uber's preferred outcomes on these issues are inefficient, and that the regulators would forge a better rule without Uber's influence. Similar questions arise with respect to Uber's attempts to have its drivers treated as independent contractors instead of employees. ${ }^{320}$

Even when regulatory entrepreneurs are fighting to improve inefficient laws, they may produce limited reform measures that meet the company's goals, but do not address larger social concerns. For example, Tesla's New Jersey law, considered a huge political victory for Tesla, is quite narrow. It only allows Tesla to operate up to four dealerships in the state. ${ }^{321}$ More significantly, it only applies to companies that manufacture zero-emissions vehicles and that were licensed by New Jersey prior to 2014-essentially, only Tesla. ${ }^{322}$ In Washington, the bill Tesla secured enables it to open as many dealerships as it likes, but the bill is similarly restricted to companies licensed in the state before 2014, which again

\footnotetext{
${ }^{316}$ See Bruce P. Keller, The Game's the Same: Why Gambling in Cyberspace Violates Federal Law, 108 YALE L.J. 1569, 1569 (1999) ("For more than a century, Americans have believed that the social ills fostered by gambling outweigh its recreational value. As a result, gambling has been extensively regulated ...."); see also Christopher Koopman \& Jim Pagels, The Doomed Crusade Against Daily Fantasy Sites, NAtional Review (Nov. 16, 2015, 4:00 AM), http://www.nationalreview.com/article/427106/doomed-crusade-against-daily-fantasy-sportschristopher-koopman-jim-pagels (criticizing the legal developments against fantasy sports company sites as paternalistic and not serving the interest of consumer protection).

${ }^{317}$ See, e.g., Thomas Lee Hazen, Filling a Regulatory Gap: It Is Time to Regulate Over-TheCounter Derivatives, 13 N.C. BANKING INST. 123, 131 (2009) ("One of the longtime premises of securities regulation is that investors need protection not only against those who would take advantage of them, but also against themselves.").

${ }^{318}$ See, e.g., Fox, supra note 283.

${ }^{319}$ Weise, supra note 30.

${ }^{320}$ Davey Alba, How Uber Plans to Fight a Looming Class-Action Suit, WIRED (Sept. 16, 2015), $\mathrm{http}: / / \mathrm{www}$.wired.com/2015/09/uber-appeals-class-action-ruling-in-worker-misclassificationlawsuit/.

${ }^{321}$ N.J.P.L. 2015, Ch. 24, NJAB 3216 (2014-2015).

${ }^{322} I d$.
} 
means just Tesla. ${ }^{323}$ Other innovators-for example, Elio Motors, which has announced plans to produce a car that retails for $\$ 6,800$ and gets 84 miles per gallon on the highway-would not qualify. ${ }^{324}$ Similarly, when Elio has lobbied states for legislation permitting it to make direct sales to consumers, the Elioenabling bills are sufficiently narrow that they do not apply to Tesla. ${ }^{325}$

These types of grandfathering rules are quite common. For instance, the Air Cargo Deregulation Act enabled the growth of the modern air cargo industry and was heavily instigated by Federal Express. ${ }^{326}$ The act gave special positive treatment to existing carriers-essentially, Federal Express and Flying Tiger Line-including a one-year window during which they could enter new markets without competition. ${ }^{327}$ But perhaps the best example comes from ResponsibleOhio, which put forward a ballot measure to legalize marijuana in Ohio-but only if it was grown at one of ten predetermined sites, all of which were owned by ResponsibleOhio. ${ }^{328}$ This would have given ResponsibleOhio a monopoly on legal marijuana sales in the state. ${ }^{329}$

As option holders, regulatory entrepreneurs, especially nascent ones, will generally favor increasing regulatory uncertainty, potentially including radical policy shifts. Such erratic policymaking may create large costs for others, especially those who require stability.

More fundamentally, some people might worry about giving business interests additional political power. ${ }^{330}$ And because much of law involves limiting and managing harms, politically empowering companies that intend to "move fast and break things" could be particularly problematic. ${ }^{331}$ For instance, Uber has flouted not only taxi regulations, but also campaign finance laws. ${ }^{332}$

\footnotetext{
323 See, e.g., Todd Bishop, Tesla Wins Battle Against Auto Dealers in Washington State, But Future Rivals Are Screwed, GEEKWIRE (Feb. 18, 2014), http://www.geekwire.com/2014/teslawins-battle-auto-dealers-washington-state-future-rivals-screwed/.

${ }^{324}$ See Lao et al., supra note 66.

325 See, e.g., id.; Michigan SB 268, available at http://www.legislature.mi.gov/documents/20152016/billintroduced/Senate/htm/2015-SIB-0268.htm.

${ }^{326}$ Fisch, supra note 212.

${ }^{327} \mathrm{Id}$.

${ }^{328}$ Graham, supra note 38.

${ }^{329}$ Id.

${ }^{330}$ Many Americans believe that big corporations and other business interests already wield too much political power. Lydia Saad, Americans Decry Power of Lobbyists, Corporations, Banks, Feds, GALluP (Apr. 11, 2011), http://www.gallup.com/poll/147026/americans-decry-powerlobbyists-corporations-banks-feds.aspx.

${ }^{331}$ See supra note 236 and accompanying text.

${ }^{332}$ Brad Schmidt, Uber Fined \$2,000 for Violating Portland Lobbying Rules, OREGON LiVE (Jan. 5 ,

http://www.oregonlive.com/portland/index.ssf/2016/01/uber_fined_2000_for_violating.html 2016), (reporting that the auditor imposed "the maximum fine because she found that Uber showed a pattern of noncompliance, noncooperation and incomplete disclosures" that "undermine[d] the City's decision-making process and contributed to the erosion of the public's confidence in the legislative result').
} 
Uber's aggressive lobbying tactics have bled into other parts of its operations as well. Uber's Operation Slog was a concerted effort to recruit drivers from rival Lyft by having paid operatives disguise their identities - they created fake Lyft accounts, linked to burner phones and new credit cards - then hail rides with Lyft. ${ }^{333}$ During those rides, the operatives would solicit their Lyft drivers to switch to Uber. ${ }^{334}$ When Lyft started offering service in New York City, Uber falsely told its drivers that New York regulations prohibited drivers from working for both Uber and Lyft. ${ }^{335}$ Uber has been dogged by persistent rumors that it had its employees order and then cancel thousands of rides from competing companies. ${ }^{336}$ Perhaps most troubling, a top Uber executive suggested spending millions of dollars on private investigators to dig up dirt on the personal lives and families of specific journalists who were critical of Uber. ${ }^{337}$ Uber has since disavowed this plan in response to public outrage. ${ }^{338}$

\footnotetext{
${ }^{333}$ See, e.g., Casey Newton, This Is Uber's Playbook for Sabotaging Lyft, TheVERGE (Aug. 26, 2014), http://www.theverge.com/2014/8/26/6067663/this-is-ubers-playbook-for-sabotaging-lyft; Alyson Shontell, OPERATION SLOG: Uber's Aggressive Plan to Steal Lyft Drivers, Revealed, BUSINESS INSIDER (Aug. 26, 2014), http://www.businessinsider.com/ubers-operation-slog-againstlyft-2014-8.

${ }^{334}$ Id.

${ }^{335}$ Erica Fink, Uber's Dirty Tricks Quantified: Rival Counts 5,560 Canceled Rides, CNN MONEY (Aug. 12, 2014), http://money.cnn.com/2014/08/11/technology/uber-fake-ride-requests-lyft/.

${ }^{336}$ Fink, supra note 335; Rip Empson, Black Car Competitor Accuses Uber Of DDoS-Style Attack; Uber Admits Tactics Are "Too Aggressive", TECHCRUNCH (Jan. 24, 2014), http://techcrunch.com/2014/01/24/black-car-competitor-accuses-uber-of-shady-conduct-ddosstyle-attack-uber-expresses-regret/. Uber's competitors have also faced similar accusations. Ryan Lawler, Uber Strikes Back, Claiming Lyft Drivers and Employees Canceled Nearly 13,000 Rides, TECHCRUNCH (Aug. 12, 2014), http://techcrunch.com/2014/08/12/uber-lyft-slap-fight/.

${ }^{337}$ Ben Smith, Uber Executive Suggests Digging Up Dirt on Journalists, BUZzFEED (Nov. 17, 2014), http://www.buzzfeed.com/bensmith/uber-executive-suggests-digging-up-dirt-onjournalists\#.nklQ88XdP; Susan Milligan, A Ride Scare Tactic?, U.S. News (Nov. 19, 2014), http://www.usnews.com/opinion/blogs/susan-milligan/2014/11/19/an-uber-executive-suggeststhe-company-target-its-media-critics; Sarah Lacy, The Moment I Learned Just How Far Uber Will Go to Silence Journalists and Attack Women, PANDO (Nov. 17, 2014), https://pando.com/2014/11/17/the-moment-i-learned-just-how-far-uber-will-go-to-silencejournalists-and-attack-women/.

${ }_{338}$ Mike Isaac, Uber Executive's Comments Leave Company Scrambling, N.Y. TIMES (Nov. 18, 2014), http://bits.blogs.nytimes.com/2014/11/18/emil-michael-of-uber-proposes-digging-intojournalists-private-lives/.
} 


\section{CONCLUSION}

Regulatory entrepreneurs abound, and include some of the world's most valuable companies, both public and private. Although companies such as Uber, Airbnb, DraftKings, Tesla, and Hyperloop are engaged in vastly different areas of business, they are all regulatory entrepreneurs: Each has built a business in an area fraught with legal issues, such as legal gray areas, unfavorable laws, and potential instability. Each of these companies has done so with the plan of remaking the legal landscape into one that supports its business. To do this, regulatory entrepreneurs blend political and economic actions in innovative ways and have changed the balance of power on many political fronts.

Moreover, we believe that companies will continue to engage in regulatory entrepreneurship in the future and perhaps will do so even more frequently. As information technology rapidly advances, it lowers the cost of political engagement. This may allow for a feedback loop in which the greater ease with which citizens can express their preferences creates new opportunities for companies to mobilize large groups of people to push for legal changes on their behalf. Companies' successes then make investors increasingly comfortable with regulatory entrepreneurship as a business strategy, which expands the already-significant infrastructure (including information technology) that supports regulatory entrepreneurship companies.

This raises the question of how regulatory entrepreneurship will ultimately affect the mix of laws and regulations that society enacts. The most successful regulatory entrepreneurs' chief source of political power is their army of activated

users. Presumably, those members of the public who form the foot soldiers in the regulatory entrepreneur's political army are furthering their own self-interest by supporting the entrepreneur, and thus stand to gain from policy change along with the entrepreneur. Thus, we are cautiously optimistic that the dynamics we describe could encourage more efficient legislative regimes, particularly at the state and local levels. Regulatory entrepreneurs are profit-seeking entities, however; there is strong reason to believe they will use their political power to pursue their own interests, with little regard to other stakeholders or society. Accordingly, regulatory entrepreneurship may have significant negative effects. How these positives and negatives weigh out will vary across different companies and circumstances. 